\title{
Evaluations of export feasibility \\ by domestic immigrant and non-immigrant entrepreneurs \\ in new technology-based firms
}

\author{
Daniela Bolzani * \\ Assistant Professor \\ Catholic University of Sacred Hearth \\ Department of Economics and Business Management Sciences \\ 5, Via Necchi - 20123 Milan (Italy) \\ Tel. +3902 72342467; Fax: +390272342670 \\ E-mail: daniela.bolzani@unicatt.it \\ Cristina Boari \\ Full Professor \\ University of Bologna \\ Department of Management \\ 34, Via Capo di Lucca - 40126 Bologna (Italy) \\ Tel. +39051 2098075; Fax: +390516390612 \\ E-mail: cristina.boari@unibo.it
}

* corresponding author

\begin{abstract}
Entrepreneurs evaluate the feasibility of future export opportunities according to individual-level factors and perceived environmental conditions. However, because individual entrepreneurs are heterogeneous in their characteristics, previous experiences, and perceptions of environment, domestic entrepreneurs will differ in their evaluations of internationalization feasibility. In this paper, we investigate whether and how one relevant source of entrepreneur heterogeneity, i.e., migrant condition, impacts the perceived feasibility of exporting opportunities. Drawing on rich primary data collected from a matched-pair sample of 71 immigrant and 69 native domestic entrepreneurs active in new technology-based firms in Italy, we find that the migrant condition positively moderates the relationship between perceived financial public support and perceived feasibility of exporting, whereas it negatively moderates the relationship between international business skills and perceived export feasibility. Additionally, we explore how results are nuanced by using different operationalizations of migrant condition. We discuss the implications of these findings for research and policy in the area of entrepreneurial internationalization.
\end{abstract}

\section{Keywords}

International entrepreneurship; exporting; opportunity evaluation; feasibility; immigrant entrepreneurs; new technology-based firms.

FINAL VERSION, ACCEPTED IN

JOURNAL OF INTERNATIONAL ENTREPRENEURSHIP (2017), FORTHCOMING 


\section{Introduction}

The key role played by individual entrepreneurs in the internationalization of their firms has been increasingly valued by both academics (e.g., Jones et al. 2011; Oviatt and McDougall 2005) and policymakers (e.g., European Commission 2010; U.S. Department of Commerce 2015). We know that entrepreneurs' characteristics matter for entrepreneurial internationalization, especially in small- and medium-sized enterprises (SMEs) (e.g., Jones et al. 2011; Martineau and Pastoriza 2016; Ruzzier et al. 2006). As suggested by literature on the cognitive underpinnings of international entrepreneurship (e.g., Acedo and Florin 2006; Jones and Casulli 2014; Zahra et al. 2005), such entrepreneurs' heterogeneity in characteristics and backgrounds influences the evaluation of entrepreneurial opportunities (Shepherd et al. 2015; Ucbasaran et al. 2009). In particular, an increasingly relevant source of entrepreneurs' heterogeneity is found in the entrepreneurs' migration background, which we might call the 'migrant condition' (Hormiga \& Bolívar-Cruz 2015). To date, the issue of opportunity evaluation by immigrant entrepreneurs deserves further investigation (Aliaga-Isla and Rialp 2013; Bolívar-Cruz et al. 2014; Kloosterman 2010; Vandor and Franke 2016) due to their increasing presence and impact in Western economies (OECD 2011).

In this paper, we study the antecedents of entrepreneurs' intentions and actions to enter foreign markets, by specifically focusing on the perceived feasibility of internationalization (e.g., Bilkey 1978; Reid 1981; Lim et al. 1991; Sommer and Haug 2011). Internationalization is a planned, intentional entrepreneurial action undertaken by entrepreneurs to realize their business visions (see Bird 1988; Shaver and Scott 1992). As suggested by models of entrepreneurial intentions (e.g., Ajzen 1991; Shapero 1982), decision making regarding such a relatively uncontrollable and risky behavior is strongly based on the evaluation of its feasibility, i.e., its degree of ease and the practical viability of future opportunities (Stevenson and Jarillo 1990; Krueger 2000). Entrepreneurs evaluate the feasibility of future cross-border opportunities 
according to individual-level factors (e.g., international and entrepreneurial experience) and perceived environmental conditions (e.g., financial and regulatory support) (Cuervo 2005; Lim et al. 2016; Martineau and Pastoriza 2016). To date, literature has not clarified whether and how migrant condition influences the development of different perceptions of internationalization feasibility for entrepreneurs working on domestic markets. In fact, on one side, previous studies have focused on entrepreneurs already active in international markets, for example those establishing business linkages to home country markets (e.g., Drori et al. 2009; Portes et al. 2002). These studies have generally found foreign-born entrepreneurs in a more advantageous position to enter and succeed into foreign markets than native entrepreneurs because they can leverage knowledge and resources from international networks (e.g., Jiang et al. 2016; Neville et al. 2014; Wang and Liu 2015). Importantly, studies have shown that immigrant entrepreneurs' skills and experiences are useful to enter and develop international business activities not only with the country of origin but also to other countries, for example through the development of cultural repertoires and flexible views of the world (e.g., Terjesen and Elam 2009), exploiting command of common language (e.g., Solano 2014), and developing multi-polar links (Bagwell, 2015).

On the other side, several studies highlighted that immigrant entrepreneurs are more likely to face compromised human, social, and financial capital, to lack business-related knowledge, to lack governmental assistance, and to face adverse regulations in the host country (e.g., Constant and Zimmerman 2006; Hammarstedt 2001). Therefore, the issue of whether immigrant entrepreneurs, because of their different exposure to national and cross-national domains, have different perceptions of potential entrepreneurial opportunities than native entrepreneurs is still awaiting further clarification (e.g., Bolívar-Cruz et al. 2014; Vandor and Franke 2016; Sundararayan and Sundararayan 2015; Kushnirovich et al. 2017). In this paper, we specifically draw a comparison between immigrant and native entrepreneurs whose firms are not yet active in foreign markets 
asking the following research question: "Do the antecedents to the perceived feasibility of internationalization affect immigrant and non-immigrant entrepreneurs differently?"

We build on theories of intentions (e.g., Ajzen 1991, 2002; Shapero 1982) to build a set of hypotheses which we test on a unique matched-pair sample of 71 foreign-born entrepreneurs (i.e., first-generation immigrants) and 69 native entrepreneurs, active in new technology-based firms in Italy, not yet internationalized, and catering to mainstream (non-ethnic) markets. The sample was selected through a very careful matching procedure, which yielded comparable samples of immigrant- and native-owned companies in terms of industry, marketed product/service, firm age, and entrepreneur characteristics. We specifically investigated perceptions of the feasibility of exporting opportunities because exporting is the primary entry mode strategy chosen by small new firms (Jones et al. 2011), such as those in our sample.

Whereas the previous international entrepreneurship literature has shown that entrepreneurs' characteristics have direct effects on internationalization outcomes (Jones et al. 2011; Ruzzier et al. 2006; Martineau and Pastoriza 2016), in this paper we focus on the immigrant status and advance knowledge about how it impacts the evaluation of internationalization opportunities. We specifically expand the literature focusing on the cognitive underpinnings of entrepreneurial internationalization (e.g., Oviatt and McDougall 2005; Sommer and Haug 2011; Zahra and George 2002; Zahra et al. 2005), and in particular that on the antecedents of entrepreneurial intentions (for reviews, Kautonen et al., 2015; Krueger et al., 2000; Schlaegel and Koenig, 2014), by showing the moderating impact of entrepreneur's migrant condition on key individual- and environmental-level factors driving the evaluation of exporting feasibility. We thereby highlight the migrant condition as a source of heterogeneity influencing how entrepreneurs interpret and mediate the perception of potential export opportunities in the pre-export phase (Jones and Casulli 2014; Oviatt and McDougall 2005). We also advance research in the field of immigrant entrepreneurship by looking 
at the internationalization of new technology-based companies (Brzozowski et al., 2013) and adding new insights into opportunity evaluation processes through a comparison between immigrant and native entrepreneurs operating on domestic markets (Solano 2015). In addition, we make a general contribution to the entrepreneurship literature by studying migrant condition as a characteristic that renders entrepreneurs heterogeneous in their entrepreneurial decision-making (Shepherd et al. 2015).

This paper is relevant to both immigrant and native entrepreneurs who are called to assess the feasibility of international opportunities and to critically understand what experiences are important to them and on which resources they can rely. Likewise, policymakers need to be aware of how entrepreneurs develop perceptions of exporting feasibility in order to design effective policies to support the development of relevant skills and to foster the availability of resources. Given the increasing participation of immigrant entrepreneurs in Western economies (OECD 2011; The Economist 2008), being aware of any differences in such perceptions between immigrant and native entrepreneurs is key to policy design.

The paper is structured as follows. We first present a theoretical overview of decisionmakers' perceptions regarding the feasibility of prospective internationalization opportunities and about the role of immigrant status, presenting our analytical model and hypotheses. Second, we illustrate our methodological approach as well as describe the sample, data and measures of relevant constructs and variables. Lastly, we present our results and their discussion, going then to conclusions regarding the potential implications and limitations of the study.

\section{Theoretical background and hypotheses}

\subsection{Evaluating the feasibility of international opportunities in the pre-export phase}


Scholarly consensus suggests that internationalization is a process (Johanson and Valhne 1977; Madsen and Servais 1997) that entails all the characteristics of a risky and uncertain entrepreneurial endeavor (Wiedersheim-Paul et al. 1978). Under these conditions, firm's international engagement is preceded by several activities that allow entrepreneurs to recognize international opportunities and set the stage for their subsequent exploitation. Focusing on exporting behavior, decision makers in the pre-export phase are especially engaged in the evaluation and exploration of the feasibility of exporting and the formation of intentions to enter foreign markets (e.g., Bilkey 1978; Reid 1981; Lim et al. 1991). Entrepreneurs examining prospective export opportunities must critically consider whether these opportunities are feasible for them and their firms, i.e., to which extent are opportunities easy to obtain and practically viable (Stevenson and Jarillo 1990; Krueger 2000). According to models of entrepreneurial intentions, the concept of perceived feasibility has been equated to the one of self-efficacy (Bandura 1997) or perceived behavioral control (Ajzen 1991, 2002), and has been shown to strongly affect subsequent decisions (e.g., Zhao et al. 2005; Schlaegel and Koenig 2014). The beliefs of feasibility are the foundation of human agency; people take actions because they believe that they can produce desired effects (or avoid undesired ones) through their actions (Bandura 2000). Entrepreneurs assess export feasibility on the base of their experiences and environments (Zahra et al 2005) and, therefore, their perceptions depend on two sets of factors. Certain factors (e.g., skills, capacities, perceived ease or self-confidence) are internal to the individual; others (e.g., environmental/social impediments, luck or other people's control over the behavior) are external to the individual (Ajzen 2002). Taken together, these elements drive people's expectations regarding the degree to which they are capable of performing target behaviors, thanks to their resources or their control over external obstacles (Ajzen 2002). The more resources and opportunities entrepreneurs think to possess, and the fewer obstacles or impediments they anticipate, the greater their perceived feasibility of exporting (Ajzen and Madden 1986). 
However, as not all available business opportunities will be equally feasible to all entrepreneurs (Krueger 2000; McMullen and Shepherd 2006; Shane 2000), it is theoretically and practically relevant to analyse whether and how entrepreneur heterogeneity impacts the perceived feasibility of entrepreneurial opportunities. In this paper, we will focus on the migrant condition of the entrepreneur as a source of heterogeneity in the evaluation of the feasibility of potential export opportunities.

\subsection{Immigrant entrepreneurs and the perceived feasibility of export}

The entrepreneur's migrant condition is a significant variable affecting the cognitive processes behind entrepreneurial opportunity recognition and evaluation (Bolívar-Cruz et al. 2014; Hormiga \& Bolívar-Cruz 2014; Sundararajan and Sundararajan 2015; Vandor and Franke 2016; Kushnirovich et al. 2017). Immigrants are a self-selected group of individuals who undertake the risks of migration to improve their lives and earnings (Constant and Zimmerman 2006) and are therefore 'more able and more highly motivated' (Chiswick 1978: 900) towards entrepreneurship in the host country than natives. We posit that migration likely represents a significant 'developmental' experience for immigrants (see Krueger 2007), which can impact their perceptions of ability and self-efficacy.

Looking at the engagement in international entrepreneurship, literature has shown that immigrant entrepreneurs have a greater likelihood of exporting than native entrepreneurs because they can rely on international networks, international work experience, cross-cultural skills, and knowledge of foreign markets (e.g., Chung 2004; Crick et al. 2001; Kloosterman et al. 1998; Saxenian 2002). It could be therefore argued that the immigrants are exposed to cross-cultural, cross-national experience, which contributes developing skills and knowledge that augment immigrants' ability to recognize, recombine, and implement entrepreneurial opportunities across 
borders (Jiang et al. 2016; Sundararajan and Sundararajan 2015; Vandor and Franke 2016). However, at the same time, migration is a stressful life event for migrants abandoning the homeland and facing integration challenges and barriers in the receiving context (Hormiga \& Bolívar-Cruz 2014). To this regard, the literature is not clear about whether and how immigrants evaluate potential international market opportunities compared to native entrepreneurs. In the following, we elaborate a model (Figure 1) to investigate the migrant condition as a source of heterogeneity in how entrepreneurs rely on experiences and interpret the environment, therefore having an impact on the way they evaluate export feasibility.

\section{Insert Figure 1 about here}

\subsubsection{Individual drivers of the perceived feasibility of exporting}

Entrepreneurs observe, interpret, and mediate international opportunities through the lens of their personal experiences (Jones and Casulli 2014; Oviatt and McDougall 2005). Experience endows entrepreneurs with resources, skills, and networks, and its elaboration induces learning and changing beliefs (Jones and Casulli 2014; Morris et al. 2012), which influence perceptions of entrepreneurial opportunities feasibility (Ajzen 2002; Krueger 1993).

One of the key drivers of international entrepreneurship is the exposure to international environments and the related development of international business skills. Previous studies have shown that entrepreneurs' overseas experience (e.g., time spent abroad for work, study, or travel) is positively associated with several internationalization outcomes (e.g., Bloodgood et al. 1996; Reuber and Fischer 1997). Because learning and ability is not generated by experience per se, international business skills will be generated through the elaboration of such experience and the consequent changes of beliefs and points of view held by people (e.g., Ajzen \& Fishbein, 1980). We reason that several mechanisms underlie the development of international business skills. 
Entrepreneurs exposed to international settings develop a global mindset (Arora et al. 2004), reduce their perceptions of distance towards foreign markets and increase their perceived capability of exporting (Madsen and Servais 1997; Manolova et al. 2002), access resources from international networks (Madsen and Servais 1997; Saxenian 2002) and gain both informational skills (that is, pertaining to the acquisition and dissemination of information about markets, customers, competitors, and distribution channels) and relationship-building capabilities (that is, regarding the understanding of and response to export requirements) (Morgan et al. 2004). Studies in the field of entrepreneurship have shown that experience and the related gained skills, either general or specific to entrepreneurship, increase entrepreneurs' perceptions of being prepared and sufficiently capable of conducting entrepreneurial activities (Krueger 1993; Krueger 2007). In line with these insights, we reason that entrepreneurs' international business skills increase their perceived feasibility of export opportunities.

Immigrant entrepreneurs experienced migration to another country, either alone or within a migrating-family environment. Such direct personal exposure to a foreign culture or the influences of close family members with foreign origins allows immigrants to develop global mindsets (Arora et al. 2004). Because they have been personally exposed to diverse international cultural environments, immigrant entrepreneurs are able to draw on and leverage knowledge about the home country, the host country, any eventual transition country, or other countries to which they might be linked through ethnic ties to recognize and exploit international opportunities (e.g., Jiang et al. 2016; Sundararajan and Sundararajan 2015). Therefore, while immigrant entrepreneurs build new networks in the host country, they remain embedded in their original country's culture (Hofstede et al. 2004) and maintain multi-stranded networks in their societies of origin and of settlement (Schiller et al. 1992; Portes et al. 2002; Rusinovic 2008). In this regard, we share the concept of 'immigrant capital' (Sundararajan and Sundararajan 2015), which is based on the 
boundary-spanning role of immigrants in multiple networks and their embeddedness in different networks (i.e., local and native country). Boundary spanning roles and cohesive networks (like those created through combinations of ties) in different environments provide the immigrant entrepreneur with two types of advantages. First, in a more practical way, they can build knowledge of foreign markets, access resources from international networks (Saxenian 2002; Jiang et al. 2016), and develop cross-cultural competences for understanding and operating with people from different national and cultural backgrounds (Madsen and Servais 1997; Muzychenko 2008; Vandor and Franke 2016), which helps increase their sense of entrepreneurial feasibility. Second, they provide immigrants with the advantage of developing cross-country cognitive schemas (Sundararajan and Sundararajan 2015), which increase their capabilities to identify and evaluate profitable opportunities (Vandor and Franke 2016). Therefore, we reason that immigrants' stock of cross-border experiences influence their cognitive processing and affective responses and, thus, raise their perceptions of their overall abilities in interpreting the typicality, meaning, impact, and overall saliency of potential new experiences and opportunities (see Morris et al. 2012; Jones and Casulli 2014).

Building on these insights, we argue that international business skills and the migrant condition rest on the same mechanism in increasing entrepreneurs' perceived feasibility of internationalization, and therefore they can act as substitutes. In fact, both international business skills and migrant condition are related to experiences carried out on international settings, which grant similar opportunities to develop a global mindset, establish international ties, and gain informational skills about both the host country and other countries. We therefore expect the relationship between international business skills and perceived feasibility of exporting to be negatively moderated by the migrant condition. In fact, two variables interact in a negative way and thus weaken each other's influence when their effects rest on the same mechanism and they 
are thus partially redundant in bringing about a particular outcome (e.g., Johnson et al. 2009). Therefore, we hypothesize the following:

Hypothesis 1: The effect of entrepreneurs' international business skills on the perceived feasibility of exporting in the pre-export stage is negatively moderated by migrant condition, such that the international business skills of immigrant entrepreneurs has a weaker effect on the perceived feasibility of exporting than that of non-immigrant entrepreneurs.

The extant literature suggests that previous entrepreneurial experience provides episodic knowledge about managerial, financial and network practices (Wright et al. 2007). Through this experience, entrepreneurs generate skills that enhance their opportunity-recognition capacities and their abilities to critically assess their competence (e.g., Minniti and Bygrave 2001; Ucbasaran et al. 2009). Entrepreneurial experience increases entrepreneurs' perceptions of being prepared and sufficiently capable of conducting entrepreneurial activities (Krueger 1993, 2007). With regard to internationalization, entrepreneurial experience can influence the perceived ability to carry out entrepreneurial activities abroad and to cope with the complexity of international operations (Birley and Westhead 1993; McDougall et al. 2003). In fact, experienced entrepreneurs in born-global firms have been found to differ in terms of learning sources, product/market innovativeness, and willingness to manage and assess risk (Odorici and Presutti 2013).

The literature on the establishment of companies by immigrant entrepreneurs has provided several insights into the peculiarities of their entrepreneurial experience. On the one hand, the literature has shown that immigrants might be 'pushed' into self-employment due to labour market obstacles or to exploit resources within ethnic enclaves (for a review, Zhou 2004). On the other hand, studies have shown that immigrant entrepreneurs can break out from traditional, ethnicbounded activities and target mainstream markets (Arrighetti et al. 2014; Ram and Hillin 1994). In 
both cases, immigrant-owned ventures face a 'liability of ethnicity', i.e., costs originating from the lack of host country legitimacy and barriers associated with the founder's immigrant status (Jiang et al. 2016). However, recent literature has shown that immigrant-owned companies can reduce the liability of ethnicity, for example, through the naturalization of the immigrant owner (Jiang et al. 2016) or an international strategy aimed at improving business performance (Jiang et al. 2016; Neville et al. 2014; Wang and Liu 2015). In line with these findings, we argue that longer entrepreneurial experience in the host country allows immigrant entrepreneurs to learn and assimilate into the host country's business environment, regulations, and firm management practices (Hammarstedt 2001; Arrighetti et al. 2014) and to build business legitimacy (Jiang et al. 2016). This, in turn, increases their abilities to network and integrate with native customers, suppliers, and other business partners, as well as their perceived effectiveness in interpreting and exploiting potential cross-border business opportunities (e.g., Jiang et al. 2016). This argument is in line with findings by Portes, Guarnizo, and Haller (2002), who have shown that transnational business activities were more prevalent among immigrant entrepreneurs with the longest immigration histories in the host country, indicating that internationalization is a route 'mainly open to immigrants who have established a secure foothold' in the host country (289). We therefore reason that immigrant entrepreneurs, being boundary spanners in cross-cultural networks (Sundararajan and Sundararajan 2015), obtain more benefits than native entrepreneurs from previous entrepreneurial experience in the host countries. In fact, having developed ties to the host country entrepreneurial networks places them in a more advantageous position than native entrepreneurs in terms of higher perceived abilities and lower barriers to potential entrepreneurial opportunities in both domestic and international markets. Thus, we hypothesize the following:

Hypothesis 2: The influence of entrepreneurial experience on the perceived feasibility of exporting in the pre-export stage is positively moderated by migrant condition, such 
that the entrepreneurial experience of immigrant entrepreneurs has a stronger positive effect on the perceived feasibility of exporting than that of non-immigrant entrepreneurs.

\subsubsection{Environmental drivers of the perceived feasibility of exporting}

The decision to export is not entirely dependent on the entrepreneur's experience; it also depends on the external business environment (Dimitratos et al. 2004; Zahra and Garvis 2000; Zahra and George 2002), particularly on external resources, barriers and challenges (Baum et al. 2013; Leonidou 2004; Sharkey et al. 1989). Decision makers' perceptions of the external environment have been acknowledged as important influences of entrepreneurial activities and firms' strategic choices, such as internationalization (Fini et al. 2012; Zahra et al. 2005). In fact, even within the same industry, entrepreneurs might have different perceptions of the environment, leading to significant differences in international entrepreneurship (Zahra and George 2002). Perceiving a supportive environment for internationalization entails perceiving the availability of resources and practical support to sustain international market entry and, thereby, greater internationalization feasibility (Manolova et al. 2002).

Environmental factors that affect the proactive adoption of international entrepreneurial behaviours identified in previous studies include governmental financial support and regulation (e.g., Ditchl et al., 1990; Leonidou 1995; Manolova et al. 2002). We first focus on the role of governmental financial intervention. Governments and public agencies can intervene to sustain internationalization by guaranteeing loans and providing subsidies or other financial incentives that help entrepreneurs explore foreign markets (e.g., support for travel, business meetings abroad, participation in trade fairs; Leonidou, 2004) or support specific investments in internationalization (Baum et al. 2013; Preece et al. 1998). The perception of public financial support can positively 
influence the perceived control that individuals have over their ability to implement entrepreneurial actions (Fini et al. 2012).

Previous research has shown that immigrant entrepreneurs are at a greater disadvantage compared to native entrepreneurs with regard to embarking on entrepreneurial endeavours in the host country. In fact, they often face hurdles such as legal and bureaucratic regulations, adverse labour market conditions, limited or non-existent name recognition, cultural unfamiliarity, language barriers, and limited access to resources (e.g., Cerdin et al. 2014; Portes and Rembaut 2006; Smallbone et al. 2003). This outsider status in a host country's social structures (Aldrich and Waldinger 1990; Portes et al. 2002; Zhou 2004) or ethnic liability (Jiang et al. 2016) has several consequences for the management and performance of their business. In particular, several studies have highlighted that the difficulties of accessing mainstream financial resources (Smallbone et al. 2003) cause immigrant entrepreneurs to rely more on informal financial resources provided by co-ethnic communities in the host country (Waldinger et al. 1990), with often negative consequences for firm growth and performance over time (e.g., Chaganti and Greene 2002). Building on this evidence, we argue that immigrant entrepreneurs will construe different evaluations of the feasibility of entrepreneurial opportunities in both domestic and international markets, depending on whether they perceive a supportive external environment. In particular, given the constraints on immigrants' financial resources for operating their businesses, the perceived availability of governmental financial support will influence how immigrant entrepreneurs construe their perceptions of entrepreneurial opportunities' feasibility. To an extent, pursuing an internationalization strategy significantly departs from serving the domestic market or the ethnic enclave, and perceptions of governmental financial support might be more important for immigrants than for native entrepreneurs in developing a sense of feasibility regarding firsttime export opportunities (see Crick et al. 2001; Saxenian 2002), reinforcing the importance of 
environmental support in making international opportunities appear easy and practically viable. We hypothesize the following:

Hypothesis 3: The effect of entrepreneurs' perceived governmental financial support on the perceived feasibility of exporting in the pre-export stage is positively moderated by migrant condition, such that perceived governmental financial support has a stronger positive effect on the perceived feasibility of exporting among immigrant entrepreneurs than among non-immigrant entrepreneurs.

Another type of environmental support can be found in the regulatory milieu. For example, McDougall (1989) demonstrated that new international ventures competed in industries that exhibited significantly higher levels of governmental protection and regulations. The perceived ease of entering foreign markets is influenced by perceived domestic regulations (e.g., restrictions on exports of certain products or into certain countries, export documentation requirements and procedures) and international regulations (e.g., entry restrictions, price controls, tax rates, and exchange controls) (Axinn 1988; Leonidou 2004; Manolova et al. 2002). Specifically, perceived supportive (restrictive) regulations will affect entrepreneurs' confidence in their ability to export and the perceived ease (difficulty) of internationalization. In fact, the regulatory environment generates trade impediments or supports that do not depend on the entrepreneurs or firms' skills, especially in SMEs (Leonidou 1995).

Immigrant entrepreneurs, like native ones, face regulatory constraints regarding the establishment and management of a company in the host country and any regulatory framework concerning potential business internationalization. However, immigrant entrepreneurs more often face legal and bureaucratic regulation hardships associated with entry and residence in the host country, as well as labour market regulations for immigrants (Cerdin et al. 2014; Portes and Rembaut 2006). As we claimed for financial support, we expect that immigrant entrepreneurs will 
construe different evaluations of the feasibility of entrepreneurial opportunities in both domestic and international markets depending on whether they perceive a supportive environment. In particular given the expected regulatory constraints, the perceptions of a supportive regulatory environment might be more important for immigrants than for native entrepreneurs in construing a sense of feasibility towards entrepreneurial actions (Crick et al. 2001; Saxenian 2002). We hypothesize the following:

Hypothesis 4: The effect of entrepreneurs' perceived regulatory support on the perceived feasibility of exporting in the pre-export stage is positively moderated by migrant condition, such that perceived regulatory support has stronger positive effects on the perceived feasibility of exporting among immigrant entrepreneurs than among non-immigrant entrepreneurs.

\section{Method}

\subsection{Sample and data collection}

This study draws on a primary data collection from entrepreneurs in new technology-based firms (NTBFs) (Colombo et al. 2004) located in the Emilia-Romagna region, Northern Italy (details in Appendix, Table A1) ${ }^{1}$. These firms represent a suitable context for studying the perceptions of feasibility, because they are potentially more interested in internationalization as a means to grow (Coviello and Jones 2004; Hart and Acs 2011; Saxenian 2002), they are key for economic development and increasingly involve immigrant entrepreneurs (Hart and Acs 2011). The focus on a specific regional context ensures a high level of internal validity by controlling for the normative

\footnotetext{
${ }^{1}$ NTBFs are defined with reference to the OECD definition of 'technology intensive' industries according to their average R\&D intensity. NTBFs can belong to 'High-Tech' (R\&D intensity above 8.5\%) or 'Medium-Tech' (R\&D intensity between $3.5 \%$ and $8.5 \%$ ) industries (Almus \& Nerlinger 1999).
} 
environment, contextual munificence, and entrepreneurial opportunities (Autio 1997). The selected region is interesting because its production system is characterized by SMEs active in innovative industries (Fini et al. 2012) and because it has one of the largest populations of immigrants entrepreneurs in Italy (IDOS 2013; Regione Emilia-Romagna 2013).

The population was identified using the official business registers managed by the Italian Chamber of Commerce system (Unioncamere). Similarly to other studies investigating immigrant entrepreneurs (e.g., Chaganti et al. 2008; Saxenian 2002), the selection of our sample was an important and complex task. The sampling and data collection were conducted in two steps. The first step concerned the selection of NTBFs owned and managed by foreign-born entrepreneurs (summary in Appendix, Table A2). To this regard, our sample of immigrant entrepreneurs is active in so-called 'cognitive-cultural activities' (Kloosterman et al. 2016). The sample was composed by independent, active, contactable firms, not yet internationalized, owned and actively managed by at least one foreign-born entrepreneur $(n=71$; response rate=50.7\%). We carried out face-to-face interviews based on structured questionnaires, through which we obtained insights about the entrepreneurs' biographies. This step was fundamental to identify key differences across immigrant entrepreneurs. For example, some of them were born abroad due to chance (e.g., born to Italian parents temporarily expatriated for family or work reasons); were born to non-Italian parents but later acquired an Italian nationality; migrated to Italy at different ages; and were born in a wide variety of countries.

In the second step of the data collection, we matched the 71 firms with firms owned by native Italian entrepreneurs. As with previous studies (e.g., Chaganti et al. 2008; Schnatterly 2003), we employed a matched-pair design, which is appropriate to analyze why similar participants have different outcomes. Matched-pair samples should be matched with regard to variables that have a strong correlation with the dependent variable to control for extraneous variables and to reduce the 
error term (Kerlinger and Lee 2000). We identified from literature the following four factors which influence the perceived feasibility of exporting: the firm's industry, the specific product/service produced, the age of the firm, and the age of the entrepreneur and found matched pairs using the business registers held by the Chamber of Commerce. Because two companies were carrying out very specific types of businesses, we could not match them with any Italian-owned company. We thus interviewed 69 Italian owner-entrepreneurs in 69 firms (response rate: 49\%).

The total sample counts 140 entrepreneurs and firms. Data were collected during 6 months in 2012 by the first author, through face-to-face interviews based on an Italian-language, structured questionnaire. As recommended by methodological guidelines for interviews in international business research (e.g., Marschan-Piekkari and Welch 2006), all the interviewed entrepreneurs were owners and active decision-makers within the sample companies (e.g., would-be decisionmakers about business internationalization choices). The questionnaire was designed with care to reduce potential sources of common method bias (Podsakoff et al. 2003) and was pre-tested on a panel of academics and entrepreneurs $(n=10)$ not involved in the study. Given our research questions, we decided to carry out face-to-face interviews with our respondents for two reasons. First, we were unable to a priori determine the level of Italian language proficiency in the immigrant portion of the sample. In this situation, conducting personal interviews would allow entrepreneurs to better comprehend the questions through interaction with a researcher fluent in other languages or assistance from other personnel present at the company, therefore trying to avoid the establishment of power dynamics due to the use of language by the researcher during the interview (Marschan-Piekkari and Welch 2006). While we ex-post found that immigrants were highly fluent in Italian language, conducting personal interviews was an advantage because, in line with previous literature, we found that, as foreigners, they were open and willing to talk to the researcher, not part of their social and professional circle (Marschan-Piekkari and Welch 2006), thus allowing us 
to obtain additional insights regarding our research interests through discussion. Second, we preferred the entrepreneurs to discuss their perceptions of potential opportunities in their natural setting (McMullen and Shepherd 2006). We collected a wide range of information about the entrepreneurs and their firms and complemented them, where possible, by secondary data (e.g., entrepreneurs' curricula vitae, companies' websites, and companies' financial statements). On average, each interview lasted 1.5 hours, for a total of more than 210 hours of personal contact with entrepreneurs.

We tested for non-response bias by comparing respondents with non-respondents (i.e., companies not interested in participating in the survey), finding no significant differences on the following dimensions: industry, province, legal form of the company, and entrepreneurs' age. We found that respondent companies were slightly younger than non-respondent ones (mean difference $=1$ year; $\mathrm{p}<.01$ ), but consider this as a negligible difference. We therefore conclude that non-response bias is not an issue in our study.

\subsection{Measures}

All the variables chosen for our empirical analysis were measured with scales and measures previously used in literature and collected from entrepreneurs evaluating a brief scenario concerning a potential future export opportunity, as summarized in Table 1.

\section{Insert Table 1 about here}

The dependent variable, perceived feasibility of exporting, was measured with a three-item, 7-point Likert scale adapted from Ajzen (2002) regarding entrepreneurs' perceived control over a potential future opportunity about exporting at least the $10 \%$ of their firms' products/services. We chose this measure because it has been shown to represent perceived feasibility of entrepreneurial behaviour (Schlaegel and Koenig 2014) and significantly predict subsequent entrepreneurial 
behaviours (e.g., Kautonen et al. 2015). The scale presented a Cronbach's alpha of .75 and was used in the analysis as a factor score.

Considering the individual antecedents of the perceived feasibility of exporting, the variable international business skills was measured with a five-item, 7-point Likert scale created by Manolova et al. (2002). This scale measures entrepreneurs' evaluations of their commercial/marketing expertise, international business education, previous international work experience, personal relationships and networks abroad as well as their technology and communication expertise. However, because the factor loadings and the item-to-test correlations were satisfactory for only four of the five items (i.e., excluding technology and communication expertise), we used only a four-item scale, which had a Cronbach's alpha of .57. This variable was used in subsequent analyses as a factor score. Entrepreneurial experience was calculated as the number of years that respondents spent working as entrepreneurs or as self-employed in the host country before opening the present firm (e.g., Politis, 2008). With regard to the environmental antecedents to the perceived feasibility of exporting, we followed other authors (e.g., Baum et al. 2013; Fini et al. 2012; Manolova et al. 2002) using entrepreneurs' perceptual measures about the support of the external environment. Specifically, the variable perceived governmental financial support was operationalized using the scale by Fini et al. (2012), and perceived regulatory support was measured adapting the scale created by Manolova et al. (2002). Both perceived governmental financial support and perceived regulatory support were analyzed as factor scores.

In this paper we explore the effects entrepreneurs' migrant condition which is measured as a dichotomous variable identifying foreign-born $v s$. native entrepreneurs (1 for foreign-born entrepreneurs, 0 otherwise).

Based on a review of the literature of the factors which can influence export outcomes and therefore perceptions of export feasibility, we added several control variables. At the individual- 
level, we controlled for entrepreneurs' age (e.g., Andersson et al. 2004), education (e.g., Carbonell et al. 2014), and gender (Brush et al. 2006). At the firm level, we controlled for age (e.g., Andersson et al. 2004), size (e.g., Bonaccorsi 1992), industry (e.g., Andersson et al. 2004; Manolova et al. 2002), financial capital (e.g., Brush et al. 2002; Westhead et al. 2001), past internationalization (e.g., Barkema and Shvyrkov 2007; Zahra et al. 2000), and international business skills of other firm members, such as other partners, managers, and employees (e.g., Bloodgood et al. 1996; Reuber and Fischer 1997).

Given our research design based on self-reported interview data, we analyzed whether our results could be affected by common method bias (Podsakoff et al. 2003). We conducted Harman's one-factor test on the self-reported set of items of interest. The unrotated principal component factor analysis extracted six different factors that accounted for $63.3 \%$ of the total variance, with the first factor explaining $14.6 \%$. We conclude that common method bias appears not to be a concern in our dataset because we could identify more than one factor and no factor accounted for most of the variance.

\section{Results}

\subsection{Sample descriptive statistics}

The 140 sampled firms were mainly active in the production of software and supply other informatics tools (30\%), production of machineries (30.7\%), production of electrical equipments (12.9\%), information and communication technology services (11.4\%), and production of computers, electronic, electro-medical and measurement equipments (10\%). The firms' location substantially mirrored that of the industrial activities in the region (Appendix, Table A3). Firms were on average established in year $2006(S D=3.70)$ by two partners, and employed 3.9 employees at the time of interview. The total available financial capital (that is, capital raised from personal 
or external funding) was on average $€ 51,919$ ( $S D=129,866$ ). Only $9.3 \%$ of companies employed managers. Around $17 \%$ of companies had carried out some internationalization activity in the past, but were not internationalized at the time of the interview.

We compared immigrant- and non-immigrant-owned firms with respect to a wide range of characteristics, such as age, size and assets, previous internationalization experience, targeted client type, localization of market, and ethnic market size. We found no significant difference across all these dimensions (Table A4 in Appendix).

The 140 entrepreneurs were primarily male $(76.4 \%)$ and 41 years old on average $(S D=8.21)$. They accomplished 15 years of education (i.e., completed secondary school and several years of post-secondary education) $(S D=3.23)$ and worked for 12.7 years on average before opening their present firms $(S D=8.24) .48 .5 \%$ of them reported previous work experience within an internationalized company and $94.2 \%$ had travelled at least once in their lives for any reason. Immigrant entrepreneurs were from a wide variety of countries (details in Table A5 in Appendix) On average, they migrated to Italy when they were 15 years old $(S D=11)$. A total of $35 \%$ worked in their country of origin (on average for 2 years).

We compared immigrant and native entrepreneurs' key characteristics, such as gender, age, education, work experience, entrepreneurial experience, international experience, foreign language proficiency, and entrepreneurial motivation. The analyses did not reveal significant differences, except for the total number of working years in Italy (i.e., immigrants have spent less working time in Italy) and foreign language skills (i.e., immigrants have a greater ability to speak at least one foreign language and have a higher level of English proficiency) (Table A6 in Appendix).

These comparative descriptive statistics confirmed that our matching-pair strategy was highly effective in locating very similar pairs with regard to a variety of aspects and highlighted some key factors to keep into account as to differentiate across entrepreneurs. 


\subsection{Test of hypotheses}

After verifying that the pairwise correlations were in the expected direction (Table 2), we tested our hypotheses using a hierarchical OLS regression, which was recommended given our interest in the interaction effects of migrant condition on the relationship between the perceived feasibility of exporting and its antecedents (Cohen and Cohen 1983). The results of our regression are reported in Table 3.

\section{Insert Table 2 and Table 3 about here}

Model 1 is a baseline model that reports the effect of the control variables on the perceived feasibility of exporting; Model 2 adds the main effects using centered independent variables to enhance the interpretability of the results (Aiken and West 1991; Cohen and Cohen 1983); and Model 3 adds the interaction terms related to entrepreneurs' migrant condition. The statistically significant increase in R-squared between each model denotes that the added variables provide an explanatory contribution that exceeds the previous. The analysis to detect multicollinearity did not reveal problems (all VIFs ranged between 1.18 and 3.64).

Results supported our hypothesized effect of migrant condition for two out of four patterns. First, we found support for our Hypothesis 1, which stated that migrant condition has a negative effect of international business skills on the perceived feasibility of exporting, acting as substitution effect for immigrant entrepreneurs. To enhance understanding of this finding, we plotted this relationship in Figure 2 (Dawson 2014). Hypothesis 2 tested whether the entrepreneurial experience of immigrants had stronger effects on the perceived feasibility of exporting. We did not find support to this supposition. Regarding the hypotheses concerning the environmental antecedents to perceived feasibility, we found support for Hypothesis 3 (Figure 3), but we did not find support for 
Hypothesis 4, which tested whether perceived regulatory support affects immigrant entrepreneurs' perceptions of export feasibility ${ }^{2}$.

\section{Insert Figures 2-3 about here}

\subsection{Robustness check}

To verify the robustness of our results, we first performed a split sample analysis of immigrantand non-immigrant entrepreneurs using Chow tests to check whether the significant main effects regression coefficients of the two groups were equal. We support our previous findings because we reject the equality of coefficients for International business skills $(\mathrm{p}<.01)$, Entrepreneurial experience $(\mathrm{p}<.01)$, Perceived financial government support $(\mathrm{p}<.01)$ and Perceived regulatory support $(\mathrm{p}<.05)$.

Second, it could be argued that the degree of acculturation in the host country might be an important variable to consider as influencing immigrant entrepreneurs' perceptions of opportunity. We thus tested our hypotheses by adding a control variable measuring immigrant entrepreneurs' orientations towards their host country, using the three-item, 5-point Likert scale created by Sánchez and Fernández (1993). Because this scale only measures the degree of acculturation for immigrants, it was not used for Italian entrepreneurs who were assigned a value equal to five. Our results confirmed the major findings discussed above (see Table A7 in the Appendix).

Third, acknowledging that differences might emerge due to the home-country conditions of migrant entrepreneurs (Elo 2016; Bolivar-Cruz et al. 2014; Brzozowski et al. 2014), we created a dichotomous variable differentiating migrants from developed $v s$. emerging/developing countries

\footnotetext{
${ }^{2}$ We considered the possibility that our scale for perceived regulatory support could average out perceptions about home country regulations and foreign country regulations. In fact, the two items could have different effects on the perceived feasibility of exporting. Therefore, in additional analyses, we tested the effects of these two items by entering them separately into the regression equation. However, we did not find any significant result.
} 
(1 for developing countries, 0 otherwise) (Bolivar-Cruz et al. 2014). We used this additional operationalizations of migrant condition to construe smaller matched-pair groups for our analyses. As shown by results in Table 4 and Figures 4 and 5, we found strong support for Hypotheses 1 and 3 , in line with main results presented above.

Insert Table 4, Figures 4-5 about here

\section{Discussion}

Exporting opportunities are not evaluated as equally feasible by all entrepreneurs because individual entrepreneurs are heterogeneous in their characteristics, skills, previous experiences, and perceptions of environmental conditions (Shepherd et al. 2015). In this paper, we have focused on a relevant source of entrepreneur heterogeneity, i.e., migrant condition, to study how immigrant and non-immigrant entrepreneurs evaluate the feasibility of future exporting opportunities in the pre-internationalization phase.

Our findings show that the migrant condition is negatively related to perceived exporting feasibility. As we have shown, our results are robust to tests regarding the immigrants' acculturation in Italy and country of origin (e.g., developed vs. developing countries). These results invite us to adopt a fine-grained reasoning about the role of perceived individual- and environmental-level drivers of feasibility in immigrant and native entrepreneurs. Drawing on insights emerging from previous literature and our field notes from interviews with entrepreneurs, we suggest two lines of reflection. First, in our context - i.e., first-generation immigrant entrepreneurs active in new technology-based firms in a Southern European country - the perceptions of environmental barriers might be more important than individual experience and skills in driving their perception of export feasibility with respect to native entrepreneurs. Second, first-generation immigrant entrepreneurs tend to focus on domestic markets (e.g., Zhou 2004; 
Westhead et al. 2001) or are pushed by necessity towards international markets (e.g., Rusinovic 2008); therefore, they are less likely to perceive their potential as exporters. For instance, the interviewed immigrant entrepreneurs reported that exporting would be a feasible option after their products were positively tested in the Italian market and sales in Italy were more stable. Looking at these findings in a broader perspective, we suggest that future studies on immigrant entrepreneurs' evaluation of opportunities should take into account how the environmental and historical setting, company-level and individual-level experiences and entrepreneurs' life stages can influence international opportunity evaluation and decision-making. This could be accomplished both through the use of qualitative, in-depth accounts about the interaction of entrepreneurs' experiences, organizational setting, and environmental conditions (e.g., countryand industry-level factors), or comparative quantitative studies considering both subjective and objective measures of these multi-level dynamics, possibly comparing industries and countries.

Our results show that international business skills have a weaker effect on the perceived feasibility of exporting for immigrant than for native entrepreneurs. In particular, one of our robustness checks shows that the negative interaction between international business skills and migrant condition is stronger for developing country immigrants. This finding is suggestive that there might be other contextual issues that make immigrant entrepreneurs evaluating international business skills as less relevant than native entrepreneurs for exploiting potential exporting opportunities. As a significant example, during our interviews, a Moroccan entrepreneur active in the fields of information and communication and procurement services explained that these types of services were 'too advanced' for the Moroccan market. On the contrary, other entrepreneurs reported that their products were not standardized enough or not unique enough to be competitive in foreign markets. These findings suggest that additional research is needed to examine how the product/market combination served by entrepreneurs, as well as the socio-economic and market 
characteristics of the target export country (e.g., home country characteristics, Brzozowski et al. 2014; target country language, Sui et al. 2015), affect immigrants' evaluation and exploitation of international opportunities. Although we acknowledge that we cannot draw any conclusions concerning the effect of international experience on the actual implementation of internationalization strategies, that is, after entry into foreign markets, these results highlight the need for further research on this topic and in different countries.

Moving to the impact of entrepreneurial experience, we found no support to our hypothesis that immigrants who were more exposed to entrepreneurial activities in the host country displayed greater perceived feasibility towards export opportunities. However, because previous studies such as Portes et al. (2002) found that the longer the residence time in the host country, the greater the likelihood that immigrant entrepreneurs conduct transnational business activities, we call for additional investigation of whether habitual immigrant entrepreneurs have different perceptions of international business opportunities than native entrepreneurs.

Going to discuss the impact of environmental drivers, we found that perceived government financial support had a significantly stronger positive effect on the feasibility of future exports among immigrants than among native entrepreneurs. Very importantly, one of our robustness checks shows that the positive interaction between perceived governmental support and migrant condition is strongest for developing-country immigrants, who, as "poor-to-rich" migrants face high institutional asymmetries when relocating to the host country (Elo 2016). The previous literature has generally found that small business owners, especially immigrant entrepreneurs (Crick et al. 2001), lack trust in government support, have poor awareness of many forms of government assistance, and utilize them poorly (Leonidou 1995). In this regard, our findings are interesting because they show that policies aimed at supporting exports might be welcomed by immigrant entrepreneurs as tools that improve their evaluations of new opportunities. While our 
study specifically deals with high-tech firms, for which perceived governmental support might play a particularly important role, it would be interesting for future studies to explore whether these findings can be replicated into more traditional sectors and in other countries which present different institutional arrangements and entrepreneurial ecosystems.

\section{Conclusion}

This paper contributes to the understanding of the micro-foundations of internationalization in the context of micro, small and medium enterprises (Jones et al. 2011) in several ways. First, it extends the literature focusing on the cognitive underpinnings of entrepreneurial internationalization (e.g., Acedo and Florin 2006; Jones and Casulli 2014; Sommer and Haug 2011; Zahra et al. 2005). Second, it presents an account of the antecedents to the evaluation of export opportunities in the rarely investigated pre-internationalization phase (Tan et al. 2007). Third, it makes a contribution to knowledge about the impact of migrant condition on the evaluation of export opportunities (e.g., Crick et al. 2001; Neville et al. 2014) by focusing on the perceptive dimensions of opportunity feasibility, comparing immigrant entrepreneurs with native ones, and considering technologybased firms. In addition, this study contributes more generally to the entrepreneurship literature by studying the migrant condition of the entrepreneur as a specific characteristic of the decision-maker that influences decision-making processes regarding opportunity assessment (Shepherd et al. 2015).

Understanding how perceptions of exporting feasibility are formed in the pre-export stage is particularly important from a managerial point of view because perceived feasibility is a key antecedent of subsequent entrepreneurial processes (Krueger 2000; McMullen and Shepherd 2006; Schlaegel and Koenig 2014). In an increasingly globalized economy, entrepreneurs are constantly faced with the question of whether the available exporting opportunities are feasible for them and 
how they can acquire the necessary skills and external supports (e.g., through learning, education, training, or networking; Krueger 2000). In addition, given that management characteristics cannot be changed over the short run (Zou and Stan 1998), the different perceptions of immigrant and native entrepreneurs about their capabilities to 'go international' might be of interest to firms that are considering establishing 'nationally diverse' management teams (e.g., Caligiuri et al. 2004; Mohr and Shoobridge 2011).

From a policy point of view, this study suggests that policies aiming to support internationalization should be designed after taking into account different background, points of view, and perceptions of targeted audiences (e.g., Carter et al. 2015). For instance, our study highlights the need to take into account different perceptions of perceived public financial support linked to entrepreneurs' migrant condition, which is an increasingly relevant characteristic to policymakers because of the growing socio-economic contributions of immigrants to Western economies (The Economist 2008; OECD 2011). Most importantly, this study focuses on immigrant entrepreneurs active in technology-based firms and, thus, on increasingly relevant 'cognitivecultural' business activities (Kloosterman et al. 2016) rather than enclave, 'mom-and-pop' ones.

Despite its relevant and novel contributions, the current study is far from conclusive and contains several limitations. First, the variables selected in this study were not the only ones that might contribute to the perceptions of export feasibility; however, we believe that these variables have the advantage of being visible and relatively easy to assess by entrepreneurs, advisors, and policymakers (Cooper et al. 1994). For example, the investigated individual-level factors might be improved or sustained via public policy interventions, such as training, advice, mobility programs, and so on. Secondly, we know that opportunity evaluation and exploitation are also influenced by the perceived desirability of entrepreneurial opportunities (Krueger 2000; Schlaegel and Koenig 2014). Therefore, future work should be directed at understanding whether immigrant and non- 
immigrant entrepreneurs differ with regard to the perceived desirability of exporting, including measuring elements such as attitudes, social norms, and values (Krueger 2000; Bolzani and Foo 2017). Thirdly, the study was conducted in a single region of a single country - Italy. While this answers calls for additional research on Southern Europe (Ilhan-Nas et al. 2011), we acknowledge that a wider geographical scope would allow a broader generalizability of results and a more nuanced representation of entrepreneurs' perceptions. Along the same lines, given that the study was focused on technology-based companies, we recognize that a wider industry comparison would be recommendable to extend the generalizability of results. Future studies should therefore replicate and extend our findings in other geographical and industrial contexts.

Notwithstanding these limitations, we believe that this study will provide academics, entrepreneurs, and policymakers with key insights concerning the impact of migrant condition in influencing entrepreneurs' prospective exporting decisions. 


\section{EXHIBITS}

\section{Table 1 - Measurement of variables: Summary}

\begin{tabular}{|c|c|}
\hline Variables & Content (a) \\
\hline $\begin{array}{l}\text { Perceived } \\
\text { exporting }\end{array}$ & $\begin{array}{l}\text { Factor score based on the following 3-items (7-point Likert scale) (Ajzen } \\
\text { 2002): entrepreneurs' assessment of perceived control over exporting, } \\
\text { difficulty of exporting, and extent to which the export decision is dependent } \\
\text { only on him/her. Alpha: .75. }\end{array}$ \\
\hline International business skills & $\begin{array}{l}\text { Factor score based on the following four items ( } 7 \text {-point Likert scale) (revised } \\
\text { from Manolova et al 2002): entrepreneurs evaluations of their } \\
\text { commercial/marketing expertise, international business education, previous } \\
\text { international work experience, personal relationships and networks abroad } \\
\text { Alpha: } .57 \text {. }\end{array}$ \\
\hline Entrepreneurial experience & $\begin{array}{l}\text { Total number of years working as an entrepreneur or a self-employed in Italy } \\
\text { before opening the present company. }\end{array}$ \\
\hline $\begin{array}{l}\text { Perceived financial government } \\
\text { support }\end{array}$ & $\begin{array}{l}\text { Factor score based on the following } 3 \text { items ( } 7 \text {-point Likert scale) (Fini et al. } \\
\text { 2012): entrepreneurs' evaluation of international, national, and regional } \\
\text { financial support. Alpha: } 95 \text {. }\end{array}$ \\
\hline Perceived institutional support & $\begin{array}{l}\text { Factor score based on the following } 2 \text { items ( } 7 \text {-point Likert scale) (Manolova } \\
\text { et al. 2002): entrepreneurs' evaluation of national and international export } \\
\text { regulations. Alpha: .85. }\end{array}$ \\
\hline Migrant condition & Dummy variable being 1 if the entrepreneur is foreign-born, 0 if native. \\
\hline Entrepreneur age & Age in years. \\
\hline Entrepreneur education & Total number of years of formal education. \\
\hline Entrepreneur gender & Dummy variable being 1 if the entrepreneur is male, 0 if female. \\
\hline $\begin{array}{l}\text { Firm members international } \\
\text { business skills }\end{array}$ & $\begin{array}{l}\text { Factor score based on entrepreneurs' evaluation of other company members' } \\
\text { (e.g., partners, managers, and employees) of the following 5-items (7-point } \\
\text { Likert scale) (Manolova et al. 2002): international work experience, personal } \\
\text { networks and relationships abroad, marketing expertise, international business } \\
\text { education, and expertise in technology and communication. Alpha: .89. }\end{array}$ \\
\hline Firm age & Number of years since establishment. \\
\hline Financial capital & Logarithm of total capital raised from personal or external sources. \\
\hline Firm size & Number of employees. \\
\hline Firm industry & $\begin{array}{l}\text { Dummy variable being } 1 \text { if the company operates in the high-tech sector, } 0 \text { for } \\
\text { medium-tech sector. }\end{array}$ \\
\hline Past internationalization & $\begin{array}{l}\text { Dummy variable being } 1 \text { if the company carried out an internationalization } \\
\text { activity in the past, not yet in place. }\end{array}$ \\
\hline
\end{tabular}

(a) All the questions were framed towards a significant potential exporting opportunity (e.g., arising from unsolicited orders, but aimed at least to $10 \%$ of annual turnover) in the future. To this regard, entrepreneurs were randomly assigned to an exporting scenario in the near future (that is, within the next three months) or in the distant future (that is, in the next year) (Tumasjan et al. 2013). Because the differences in means of the collected variables with respect to the two experimental groups were not statistically significant, in this paper we pooled all the answers. 


\section{Table 2 - Correlation table}

Note: migrant condition operationalized as foreign born vs. native entrepreneurs

\begin{tabular}{|c|c|c|c|c|c|c|c|c|c|c|c|c|c|c|c|c|c|}
\hline & Variables & Mean & SD & 1 & 2 & 3 & 4 & 5 & 6 & 7 & 8 & 9 & 10 & 11 & 12 & 13 & 14 \\
\hline 1 & $\begin{array}{l}\text { Perceived feasibility of } \\
\text { exporting }\end{array}$ & 2.90 & 1.62 & 1 & & & & & & & & & & & & & \\
\hline 2 & Entrepreneur age & 41.47 & 8.21 & $.175^{*}$ & 1 & & & & & & & & & & & & \\
\hline 3 & Entrepreneur education & 15.02 & 3.23 & .071 & -.152 & 1 & & & & & & & & & & & \\
\hline 4 & Entrepreneur gender & .76 & .43 & .017 & .065 & -.049 & 1 & & & & & & & & & & \\
\hline 5 & Firm age & 5.86 & 3.69 & .049 & $.204 *$ & $-.223 * *$ & .062 & 1 & & & & & & & & & \\
\hline 6 & Firm size & 3.96 & 7.49 & $.195^{* *}$ & $.223^{* *}$ & -.104 & -.003 & .050 & 1 & & & & & & & & \\
\hline 7 & $\begin{array}{l}\text { Firm industry } \\
\text { Firm past }\end{array}$ & .68 & .47 & -.053 & -.061 & $.219^{* *}$ & $-.166^{*}$ & -.096 & -.012 & 1 & & & & & & & \\
\hline 8 & $\begin{array}{l}\text { internationalization } \\
\text { Firm member international }\end{array}$ & .17 & .38 & $.205^{*}$ & $.169^{*}$ & -.121 & -.015 & .068 & .106 & $-.215^{*}$ & 1 & & & & & & \\
\hline 9 & business skills & 2.54 & 1.87 & .060 & .005 & $.182 *$ & -.076 & -.081 & .154 & .070 & -.151 & 1 & & & & & \\
\hline 10 & Financial capital & 9.52 & 2.24 & .041 & .054 & .038 & $-.218^{* *}$ & -.033 & $.211^{*}$ & -.151 & -.059 & $.360^{* * *}$ & 1 & & & & \\
\hline 11 & Migrant condition & .51 & .50 & -.148 & -.029 & .131 & -.109 & -.048 & -.012 & -.006 & -.082 & .102 & -.055 & 1 & & & \\
\hline 12 & International business skills & 3.35 & 1.46 & $.276^{* * *}$ & .156 & $.308 * * *$ & .115 & -.134 & .016 & .094 & .108 & $.249 * *$ & -.021 & $.200^{*}$ & 1 & & \\
\hline 13 & $\begin{array}{l}\text { Entrepreneurial experience } \\
\text { Perceived financial govern. }\end{array}$ & 9.31 & 6.84 & .017 & $.420 * * *$ & -.150 & .103 & $.387 * * *$ & .063 & .066 & .097 & .054 & .060 & -.075 & -.011 & 1 & \\
\hline 14 & $\begin{array}{l}\text { support } \\
\text { Perceived regulatory }\end{array}$ & 2.35 & 1.83 & $.173^{*}$ & -.034 & .073 & -.148 & -.047 & -.041 & .066 & .023 & .039 & $.190^{*}$ & -.147 & -.083 & -.056 & 1 \\
\hline 15 & support & 2.24 & 1.53 & .113 & .010 & -.028 & -.072 & .083 & -.050 & .064 & .002 & .001 & -.021 & -.204 & .069 & -.076 & $.194 *$ \\
\hline
\end{tabular}

$$
\begin{aligned}
& \mathrm{N}=140 \\
& * * * \mathrm{p}<.001 ; * * \mathrm{p}<.01 ; * \mathrm{p}<.05
\end{aligned}
$$


Table 3 - Results from OLS hierarchical regression

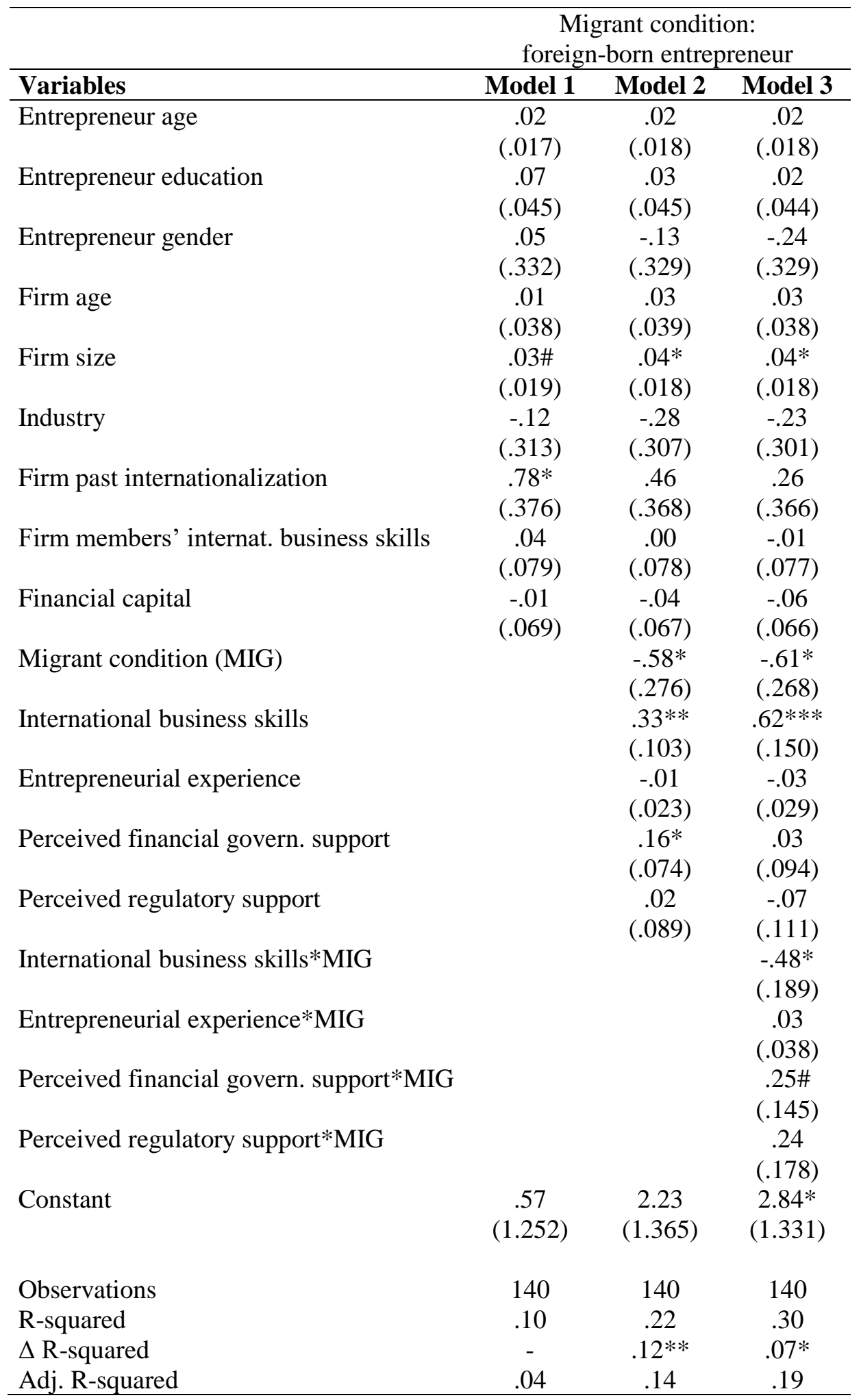

Standard errors in parentheses

$* * * \mathrm{p}<.001, * * \mathrm{p}<.01, * \mathrm{p}<.05, \# \mathrm{p}<.1$ 
Table 4 - Results from OLS hierarchical regression - robustness check

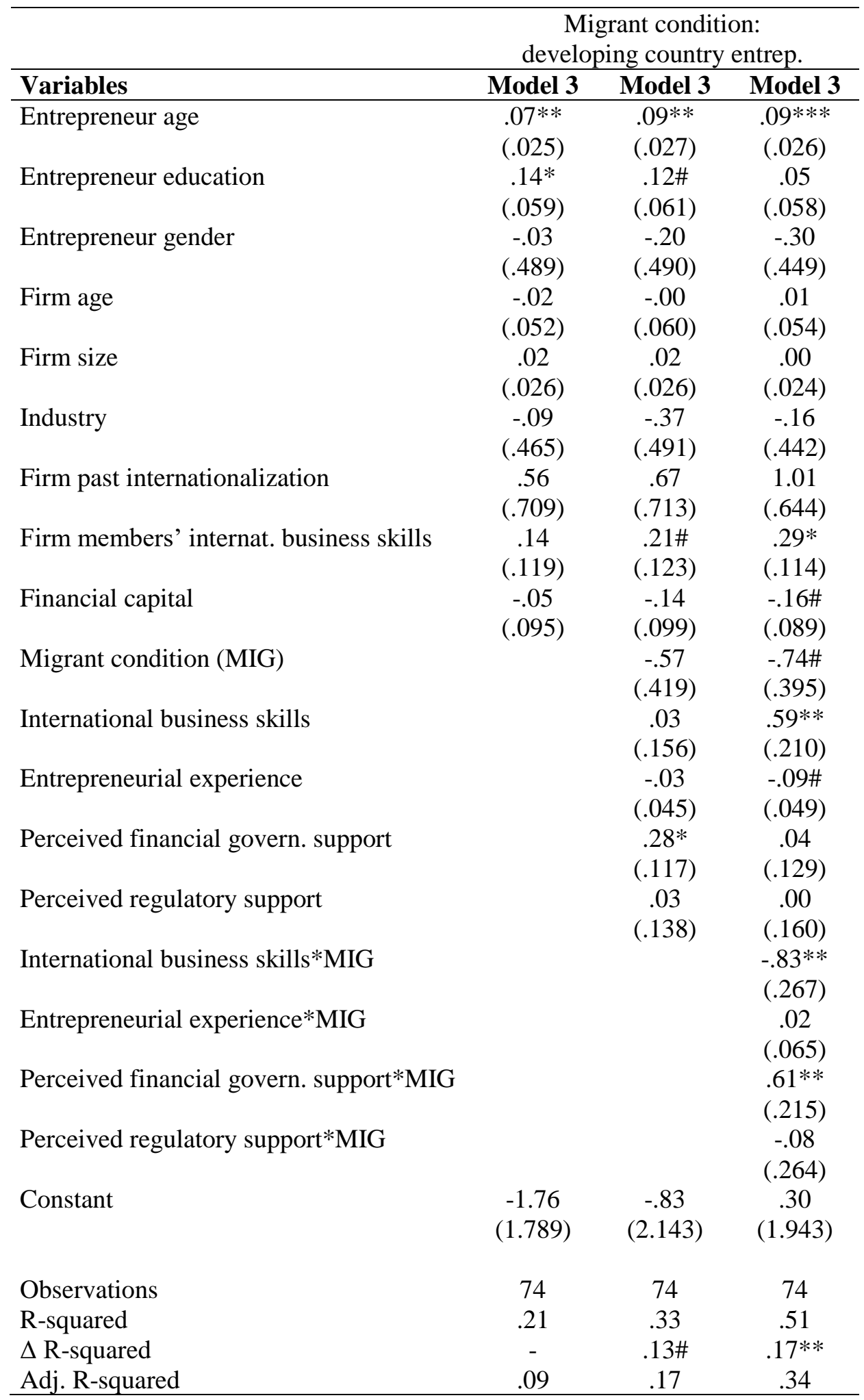

Standard errors in parentheses

$* * * \mathrm{p}<.001, * * \mathrm{p}<.01, * \mathrm{p}<.05, \# \mathrm{p}<.1$ 
Figure 1 - Analytical model

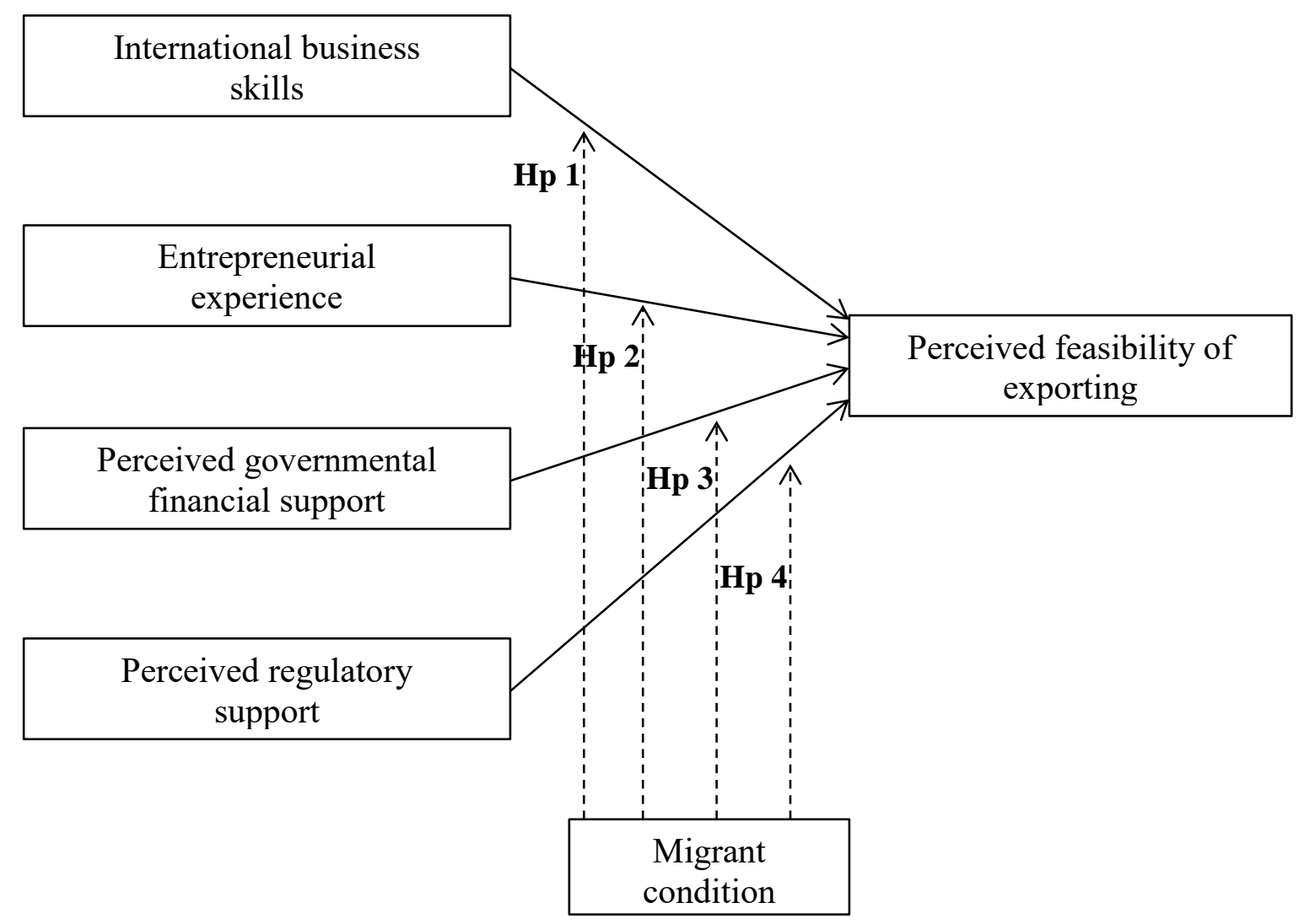


Figure 2 - Interaction effects between international business skills and migrant condition on perceived feasibility of exporting

Note: migrant condition operationalized as foreign-born vs. native entrepreneurs

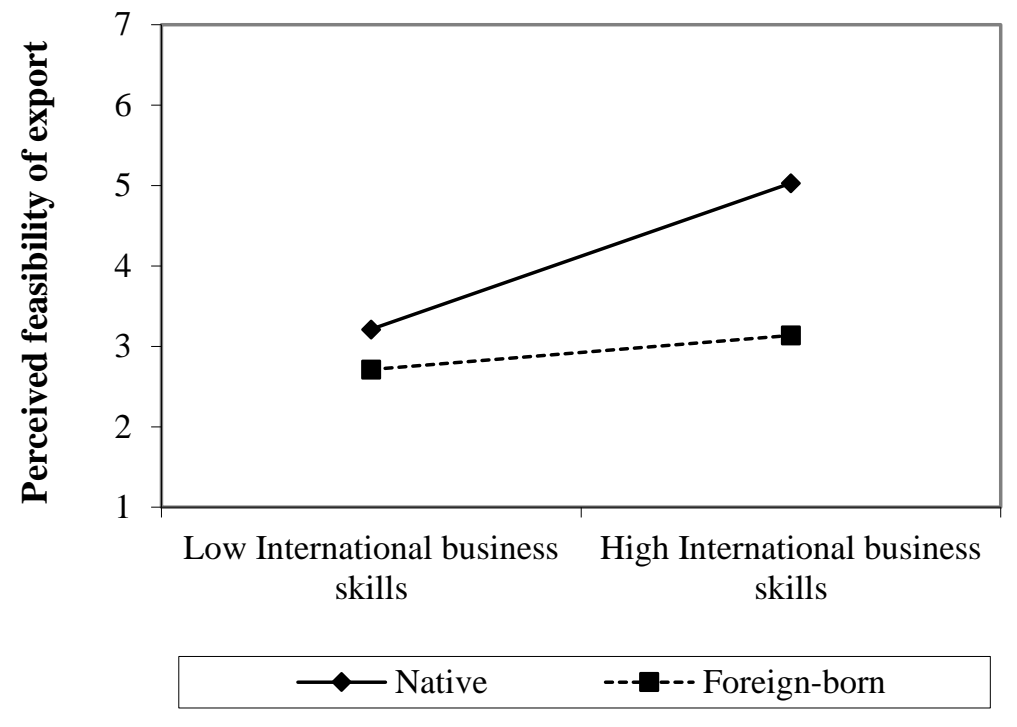

Figure 3 - Interaction effects between perceived governmental financial support and migrant condition on perceived feasibility of exporting

Note: migrant condition operationalized as foreign-born vs. native entrepreneurs

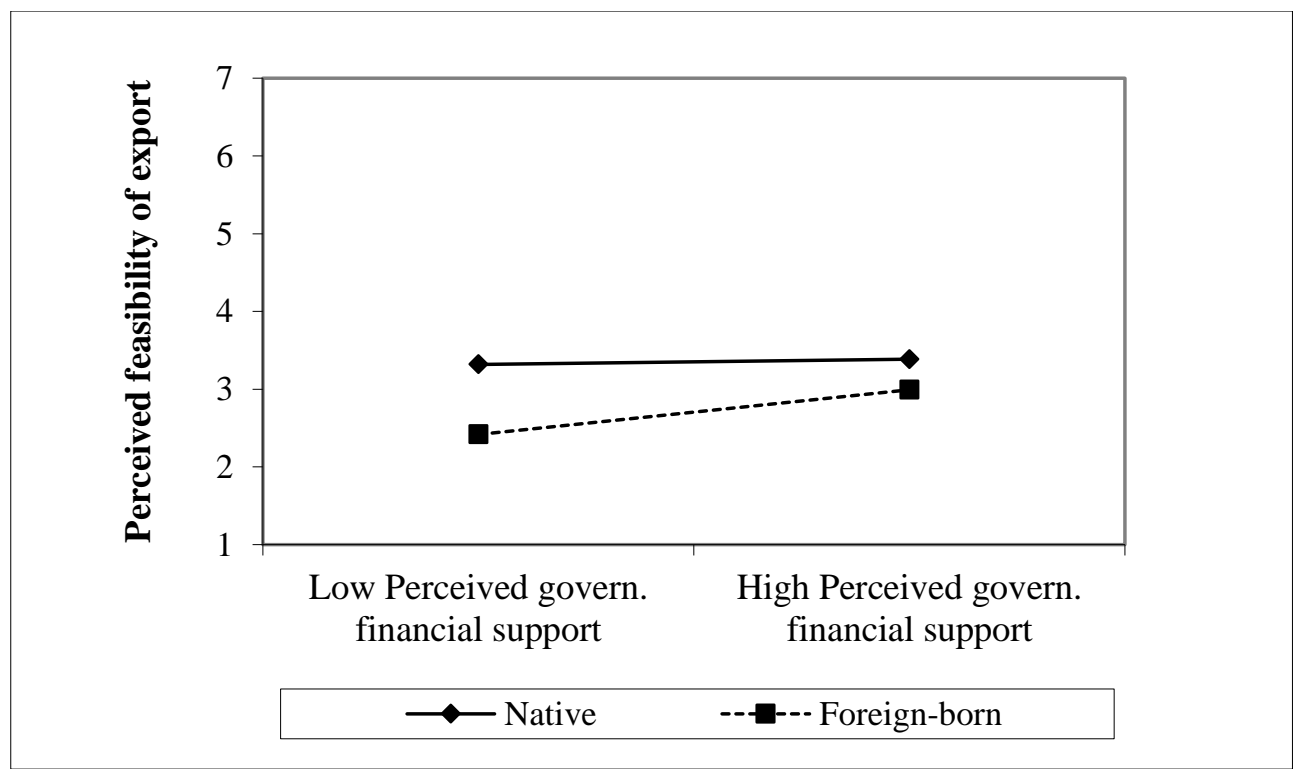


Figure 4 - Interaction effects between international business skills and migrant condition on perceived feasibility of exporting

Note: migrant condition operationalized as developing-country-immigrant vs. native entrepreneurs

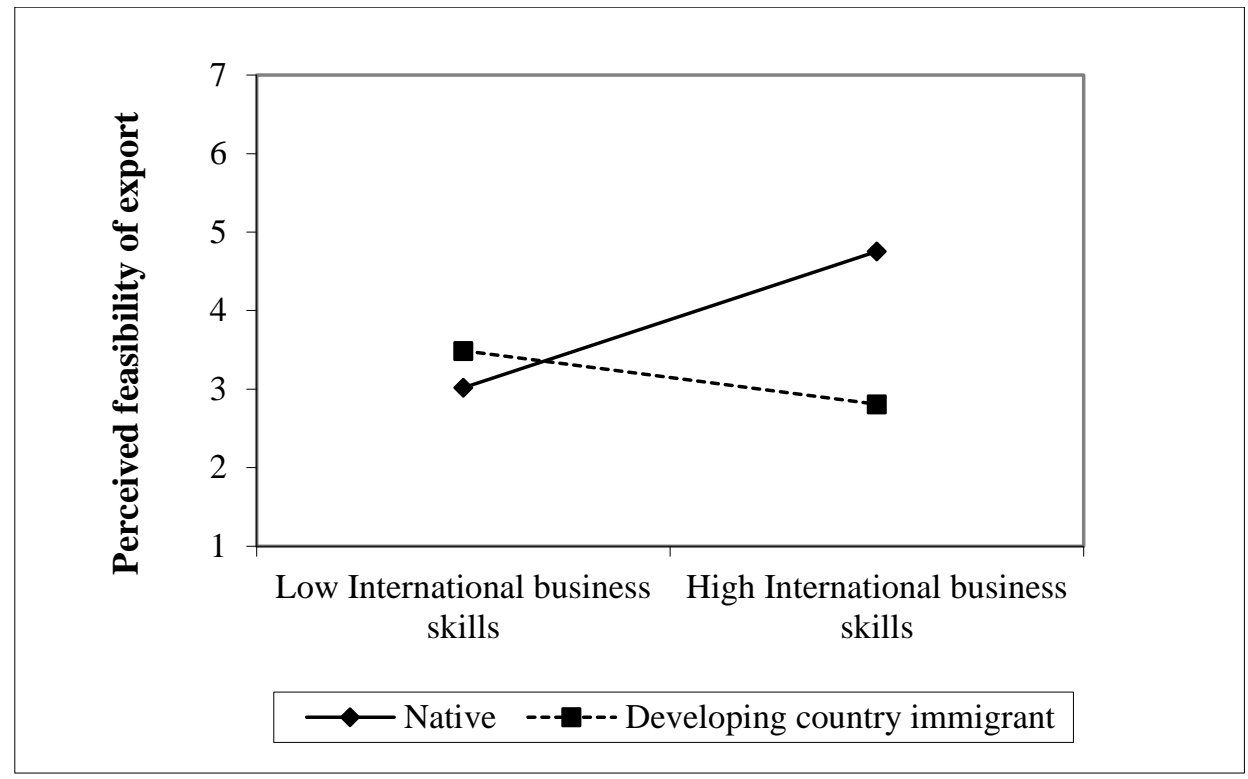

Figure 5 - Interaction effects between perceived governmental financial support and migrant condition on perceived feasibility of exporting

Note: migrant condition operationalized as developing-country-immigrant vs. native entrepreneurs

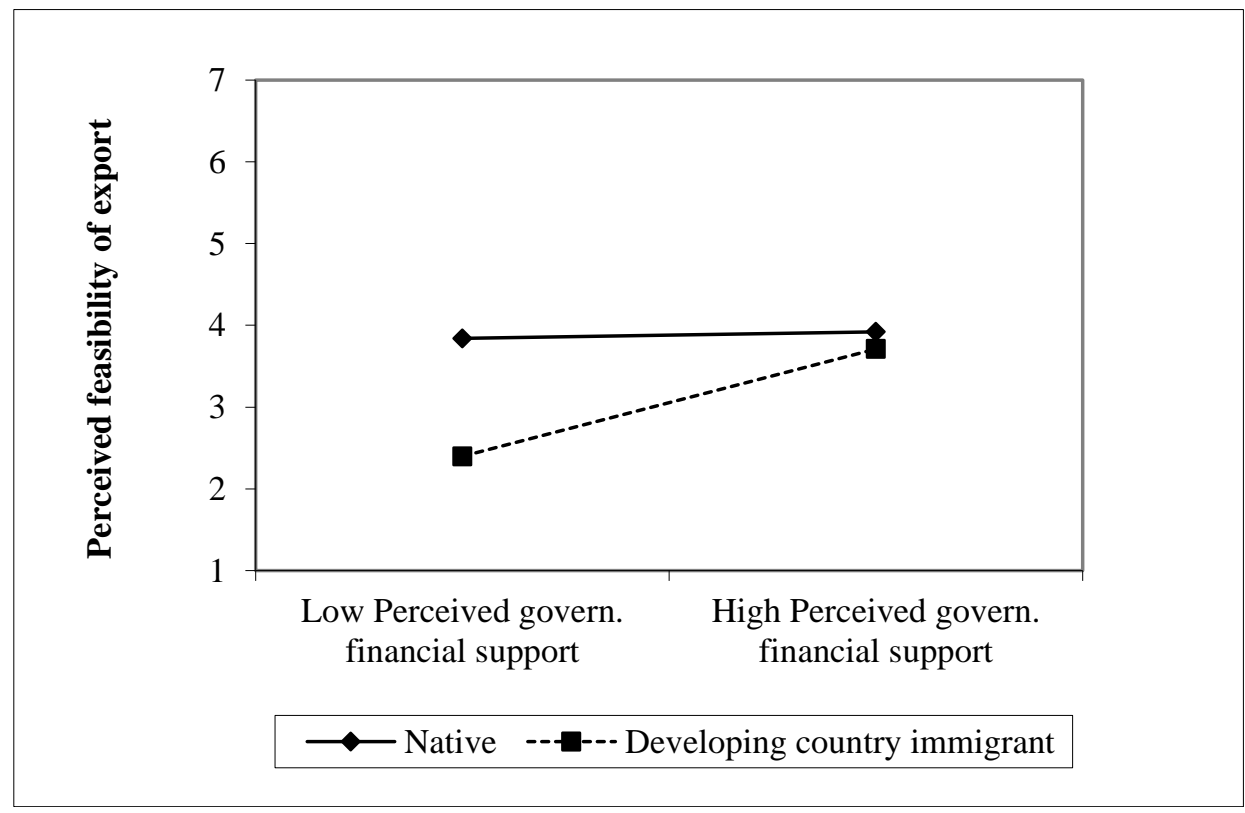




\section{REFERENCES}

Acedo FJ, Florin J (2006) An entrepreneurial cognition perspective on the internationalization of SMEs. J Int Entrep 4(1): 49-67.

Aiken LS, West SG (1991) Multiple regression: testing and interpreting interactions. New York, Sage. Aliaga-Isla R, Rialp A (2013) Systematic review of immigrant entrepreneurship literature: previous findings and ways forward. Entrep Reg Dev 25(9-10): 819-844.

Aldrich HE., Waldinger R (1990) Ethnicity and entrepreneurship. Annu Rev Sociol: 111-135.

Ajzen I (1991) The theory of planned behavior. Organizational Behavior and Human Decision Processes 50: 179-211.

Ajzen I (2002) Perceived behavioral control, self-Efficacy, locus of control, and the theory of planned behavior. J App Soc Psychol 32(4): 665-683.

Ajzen I, Fishbein M (1980) Understanding attitudes and predicting social behavior. Englewood Cliffs, Prentice Hall.

Ajzen I, Madden TJ (1986) Prediction of goal-directed behavior: attitudes, intentions, and perceived behavioral control. J Exp Soc Psychol 22: 453-474.

Almus M, Nerlinger EA (1999) Growth of new technology-based firms: Which factors matter?. Small Bus Econ 13: 141-154.

Andersson S, Gabrielsson J, Wictor I (2004) International activities in small firms: examining factors influencing the internationalization and export growth of small firms. Can J Admin Sci 21(1): 22-34. Arora A, Jaju A, Kefalas AG, Perenich T (2004) An explanatory analysis of global managerial mindsets: a case of U.S. textile and apparel industry. J Int Manag 10: 393-411.

Arrighetti A, Bolzani D, Lasagni A (2014) Beyond the enclave? Break-outs into mainstream markets and multicultural hybridism in ethnic firms. Entrep Reg Dev 26(9-10): 753-777. 
Autio E (1997) New, technology-based firms in innovation networks symplectic and generative impacts. Res Pol 26: 263-281.

Axinn CN (1988) Export Performance: do managerial perceptions make a difference?. Int Market Rev 5(2): 61-71.

Bagwell S. (2015). Transnational Entrepreneurship amongst Vietnamese Businesses in London. Journal of Ethnic and Migration Studies, 41(2), 329-349.

Bandura A (1997) Self-efficacy: The exercise of control. New York, Freeman.

Bandura A (2000) Exercise of human agency trough collective efficacy. Curr Dir Psychol Sci 9: 75-78.

Barkema HG, Shvyrkov O (2007) Does top management team diversity promote or hamper foreign expansion?. Strat Manag J 28: 663-680.

Baum M, Schwens C, Kabst R (2013) International as opposed to domestic new venturing: The moderating role of perceived barriers to internationalization. Int Small Bus J 31: 536-562.

Bilkey WJ (1978) An attempted integration of the literature on the export behavior of firms. J Int Bus Stud 9(1): 33-46.

Bird B (1988) Implementing entrepreneurial ideas: the case for intentions. Academy of Management Review 13: 442-454.

Birley S, Westhead P (1993) A comparison of new businesses established by 'novice' and 'habitual' founders in Great Britain. Int Small Bus J 12(1): 38-60.

Bloodgood JM, Sapienza HJ, Almeida JG (1996) The internationalization of new high-potential U.S. ventures: antecedents and outcomes. Entrep Theory Pract 20(4): 61-76.

Bolívar-Cruz A, Batista-Canino RM, Hormiga E (2014) Differences in the perception and exploitation of entrepreneurial opportunities by immigrants. J Bus Vent Ins 1-2: 31-36.

Bolzani D., Foo MD (2017) The 'why' of international entrepreneurship: Insights into the role of personal values. Small Bus Econ (forthcoming). 
Bonaccorsi A (1992) On the Relationship between Firm Size and Export Intensity. J Int Bus Stud 23(4): 605-635.

Brush CG, Edelman LF, Manolova T (2002) The impact of resources on small firm internationalization. J Small Bus Strat 13(1): 1-17.

Brzozowski J, Cucculelli M, Surdej A (2014) Transnational ties and performance of immigrant entrepreneurs: The role of home-country conditions. Entrep Reg Dev 26(7-8): 546-573.

Caligiuri P, Lazarova M, Zehetbauer S (2004) Top managers' national diversity and boundary spanning. J Manag Dev 23(9): 848-859.

Carbonell JR, Hernandez JCP, García FJL (2014) Business creation by immigrant entrepreneurs in the Valencian community. The influence of education. Int Entrep Manag J 10(2): 409-426.

Carter S, Mwaura S, Ram M, Trehan K, Jones T (2015) Barriers to ethnic minority and women's enterprise: Existing evidence, policy tensions and unsettled questions. Int Small Bus J 33(1): 49-69.

Cerdin JL, Diné MA, Brewster C (2014) Qualified immigrants'success: Exploring the motivation to migrate and to integrate. J Int Bus Stud 45: 151-168.

Chaganti R, Greene PG (2002) Who Are ethnic entrepreneurs? A study of entrepreneurs' ethnic involvement and business characteristics. J Small Bus Manag 40(2): 126-143.

Chaganti RRS, Watts AD, Chaganti R, Zimmerman-Treichel M (2008) Ethnic-immigrants in founding teams: Effects on prospector strategy and performance in new Internet ventures. $\mathrm{J}$ Bus Vent 23: 113139.

Chiswick BR (1978) The effect of americanization on the earnings of foreign-born men. J Pol Econ 86(5): 897-921.

Chung HFL (2004) An empirical investigation of immigrant effects: the experience of firms operating in the emerging markets. Int Bus Rev 13(6): 705-728. 
Cohen J, Cohen P (1983) Applied Multiple Regression/correlation Analysis for the Behavioral Sciences. Hillsdale, NJ, Lawrence Erlbaum Associates.

Colombo MG, Del Mastro M, Grilli L (2004) Entrepreneurs' human capital and the start-up size of new technology-based firms. Int J Indust Org 22: 1183-1211.

Constant A, Zimmerman K (2006) The making of entrepreneurs in Germany: are native men and immigrants alike?. Small Bus Econ 26(3): 279-300.

Cooper AC, Gimeno-Gascon FJ, Woo CY (1994) Initial human and financial capital predictors of new venture performance. J Bus Vent 9(5): 371-395.

Coviello NE, Jones MV (2004) Methodological issues in international entrepreneurship research. J Bus Vent 19: 485-508.

Crick D, Chaudhry S, Batstone S (2001) An investigation into the overseas expansion of small Asianowned U.K firms. Small Bus Econ 16(2): 75-94.

Cuervo A (2005) Individual and environmental determinants of entrepreneurship. Int Entrep Manag J 1(3): 293-311.

Dawson JF (2014) Moderation in management research: What, why, when and how. J Bus Psych 29: 119.

Dimitratos P, Lioukas S, Carter S (2004) The relationship between entrepreneurship and international performance: The importance of domestic environment. Int Bus Rev 13: 19-41.

Ditchl E, Koeglmayr HG, Mueller S (1990) International orientation as a precondition for export success. J Int Bus Stud 21(1): 23-40.

Drori I, Honig B, Wright M (2009). Transnational entrepreneurship: An emergent field of study. Entrep Theory Pract 33(5): 1001-1022.

Elo M (2016). Typology of diaspora entrepreneurship: Case studies in Uzbekistan. J Int Entrep 14(1): 121-155. 
European Commission (2010) Internationalization of European SMEs. Report, Entrepreneurship Unit, Brussels. http://ec.europa.eu/enterprise/policies/sme/marketaccess/files/internationalisation_of_european_smes_final_en.pdf+\&cd=1\&hl=it\&ct=clnk\&gl=it. Accessed 15 August 2015.

Fini R, Grimaldi R, Marzocchi GL, Sobrero M (2012) The determinants of corporate entrepreneurial intention within small and newly established firms. Entrep Theory Pract 36: 387-414.

Hammarstedt M (2001) Immigrant self-employment in Sweden-its variation and some possible determinants. Entrep Reg Dev 13(2): 147-161.

Hart DM, Acs ZJ (2011) High-tech immigrant entrepreneurship in the United States. Econ Dev Quart 25(2): 116-119.

Hofstede G, Noorderhaven NG, Thurik AR, Uhlaner LM, Wennekers ARM, Wildeman RE (2004) Culture. In Brown TE, Ulijn J (eds) Innovation, Entrepreneurship and Culture. Cheltenham, Edward Elgar, pp 162-203.

Hormiga E, Bolívar-Cruz A (2014) The relationship between the migration experience and risk perception: A factor in the decision to become an entrepreneur. Int Entrep Manag J 10(2): 297-317. IDOS (2013) Dossier Statistico Immigrazione 2013 - Rapporto UNAR. Rome, IDOS.

Ilhan-Nas T, Sahin K, Cilingir Z (2011) International ethnic entrepreneurship: antecedents, outcomes and environmental context. Int Bus Rev 20: 614-626.

Jiang G, Kotabe M, Hamilton III RD, Winston Smith S (2016) Early internationalization and the role of immigration in new venture survival. Int Bus Rev 25(6): 1285-1296.

Johanson J, Vahlne JE (1977) The internationalization process of the firm: a model of knowledge development on increasing foreign commitments. J Int Bus Stud 8(1): 23-32.

Johnson RE, Groff KW, Taing MU (2009) Nature of the interactions among organizational commitments: Complementary, competitive or synergistic? Brit J Manag 20: 431-447. 
Jones MV, Casulli L (2014) International entrepreneurship: Exploring the logic and the utility of individual experience through comparative reasoning approaches. Entrep Theory Pract 38(1): 45-69.

Jones MV, Coviello N, Tang, YK (2011) International entrepreneurship research (1989-2009): a domain ontology and thematic analysis. J Bus Vent 26: 632-659.

Kautonen T, van Gelderen M, Fink M. (2015) Robustness of the theory of planned behavior in predicting entrepreneurial intentions and actions. Entrep Theory Pract 39(3): 655-674.

Kerlinger FN, Lee HB (2000) Foundations of Behavioral Research. Fort Worth, Harcourt College Publishers.

Kloosterman RC (2010) Matching opportunities with resources: A framework for analysing (migrant) entrepreneurship from a mixed embeddedness perspective. Entrep Reg Dev 22(1): 25-45.

Kloosterman RC, van der Leun JP, Rath J (1998) Across the border, economic opportunities, social capital and informal business activities of immigrants. J Ethnic Migrat Stud 24(2): 249-268.

Kloosterman RC, Rusinovic K, Yeboah D (2016) Super-diverse migrants: similar trajectories? Ghanaian entrepreneurship in the Netherlands seen from a mixed embeddedness perspective. J Ethnic Migrat Stud 42(6): 913-932.

Krueger NF (1993) The impact of prior entrepreneurial exposure on perceptions of new venture feasibility and desirability. Entrep Theory Pract 18(1): 5-21.

Krueger NF (2000) The cognitive infrastructure of opportunity emergence. Entrep Theory Pract 24(3): $5-23$.

Krueger NF (2007) What lies beneath? The experiential essence of entrepreneurial thinking. Entrep Theory Pract 31(1): 123-138.

Krueger NF, Reilly MD, Carsrud AL (2000) Competing Models of Entrepreneurial Intentions. J Bus Vent 15: 411-432. 
Kushnirovich N, Heilbrunn S, Davidovich L (2017) Diversity of Entrepreneurial Perceptions: Immigrants vs. Native Population. European Management Review, online first.

Leonidou LC (1995) Export stimulation research: review, evaluation and integration. Int Bus Rev 4: 133-156.

Leonidou LC (2004) An analysis of the barriers hindering small business export development. J Small Bus Manag 42: 279-302.

Lim JS, Sharkey TW, Kim KI (1991) An empirical test of an export adoption mode. Manag Int Rev 31(1): 51-62.

Lim DS, Oh CH, De Clercq D. (2016) Engagement in entrepreneurship in emerging economies: Interactive effects of individual-level factors and institutional conditions. Int Bus Rev 25(4): 933945.

Madsen TK, Servais P (1997) The internationalization of born globals: an evolutionary process? Int Bus Rev 6(6): 561-583.

Manolova TS, Brush CV, Edelman LF, Greene PG (2002) Internationalization of small firms: personal factors revisited. Int Small Bus J 20(1): 9-31.

Marschan-Piekkari R, Welch C (2006) Reflections on using qualitative research methods in international business. Liiketaloudellinen Aikakauskirja 4, 565-574.

Martineau C, Pastoriza D (2016) International involvement of established SMEs: A systematic review of antecedents, outcomes and moderators. Int Bus Rev 25(2): 458-470.

McDougall PP (1989) International versus domestic entrepreneurship: new venture strategic behavior and industry structure. J Bus Vent 4(6): 387-400.

McDougall PP, Oviatt BM, Shrader RC (2003) A comparison of international and domestic new ventures. J Int Entrep 1(1): 59-82. 
McMullen JS, Shepherd DA (2006) Entrepreneurial action and the role of uncertainty in the theory of the entrepreneur. Acad Manag Rev 31: 132-152.

Minniti M, Bygrave W (2001) A dynamic model of entrepreneurial learning. Entrep Theory Pract 25(3): $5-16$.

Mohr A, Shoobridge GE (2011) The role of multi-ethnic workforces in the internationalisation of SMEs. J Small Bus Enterp Dev 18(4): 748-763.

Morgan NA, Kaleka A, Katsikeas CS (2004) Antecedents of export venture performance: A theoretical model and empirical assessment. J Market 68: 90-108.

Morris MH, Kuratko DF, Schindehutte M, Spivak AJ (2012) Framing the entrepreneurial experience. Entrep Theory Pract 36(1): 11-40.

Mustafa M, Chen S (2010) The strength of family networks in transnational immigrant entrepreneurship. Thunderbird Int Bus Rev 52(2): 97-106.

Muzychenko O (2008) Cross-cultural entrepreneurial competence in identifying international business opportunities. Europ Manag J 26: 366- 377.

Neville F, Orser B, Riding A, Jung O (2014) Do young firms owned by recent immigrants outperform other young firms? J Bus Vent 29(1): 55-71.

Odorici V, Presutti M (2013) The entrepreneurial experience and strategic orientation of high-tech born global start-ups: An analysis of novice and habitual entrepreneurs. J Int Entrep 11(3): 268-291.

OECD (2011) International Migration Outlook: SOPEMI 2011. Paris, OECD Publishing.

Oviatt BM, McDougall PP (2005) Defining international entrepreneurship and modeling the speed of internationalization. Entrep Theory Practice 29: 537-553.

Podsakoff PM, MacKenzie S, Lee JY, Podsakoff NP (2003) Common method biases in behavioral research: a critical review of the literature and recommended remedies. J App Psych 88: 879-903. 
Politis D (2008) Does prior start-up experience matter for entrepreneurs' learning? A comparison between novice and habitual entrepreneurs. J Small Bus Enterpr Dev 15(3): 472-489.

Portes A, Guarnizo LE, Haller WJ (2002) Transnational entrepreneurs: an alternative form of immigrant economic adaptation. Amer Sociol Rev 67(2): 278-298.

Portes A, Rembaut RG (2006) Immigrant America: a portrait. Berkeley, University of California Press.

Preece SB, Miles G, Baetz MC (1998) Explaining the international intensity and global diversity of early-stage technology-based firms. J Bus Vent 14(3): 259-281.

Ram M, Hillin G (1994) Achieving “break-out”: developing mainstream ethnic minority business. Small Bus Enterpr Dev 1(1): 15-21.

Regione Emilia Romagna (2013) Immigrazione (L') straniera in Emilia-Romagna. Edizione 2013. Bologna, Osservatorio regionale sul fenomeno migratorio.

Reid SD (1981) The decision-maker and export entry and expansion. J Int Bus Stud 12: 101-111.

Reuber RA, Fischer E (1997) The influence of the management team's international experience on the internationalization behaviors of SMEs. J Int Bus Stud 28: 807-825.

Rusinovic K (2008) Transnational embeddedness: transnational activities and networks among first- and second-generation immigrant entrepreneurs in the Netherlands. J Ethnic Migrat Stud 34(3): 431-451.

Ruzzier M, Hisrich RD, Antoncic B (2006) SME internationalization research: Past, present, and future. J Small Bus Enterpr Dev 13(4): 476-497.

Sánchez JI, Fernández DM (1993) Acculturative stress among Hispanics: A bidimensional model of ethnic identification. J App Soc Psych 23(8): 654-668.

Saxenian AL (2002) Silicon Valley's new immigrant high-growth entrepreneurs. Econ Dev Quart 16(1): 20-31.

Schiller NG, Basch L, Blanc-Szanton C (1992) Transnationalism: A new analytic framework for understanding migration. Ann New York Acad Sci 645(1): 1-24. 
Schlaegel C, Koenig M (2014) Determinants of entrepreneurial intent: A meta-analytic test and integration of competing models. Entrep Theory Pract 38(2): 291-332.

Schnatterly K (2003) Increasing firm value through detection and prevention of white-collar crime. Strat Manag J 24: 587-614.

Shane S (2000) Prior knowledge and the discovery of entrepreneurial opportunities. Org Sci 11: 448469.

Shapero A (1982) Social dimensions of entrepreneurship. In Kent C, Sexton D, Vesper K (eds.) Encyclopedia of entrepreneurship. Englewood Cliffs, Prentice Hall: 72-90.

Sharkey TW, Lim JS, Kim, KI (1989) Export development and perceived export barriers: an empirical analysis of small firms. Manag Int Rev 29(2): 33-40.

Shaver K, Scott L (1992) Person, process, and choice: the psychology of new venture creation. Entrep Theory Pract 16: 23-45.

Shepherd DA, Williams TA, Patzelt H (2015) Thinking about entrepreneurial decision making review and research agenda. J Manag 41(1): 11-46.

Smallbone D, Ram M, Deakins D, Baldlock R (2003) Access to finance by ethnic minority in the UK. Int Small Bus J 21(3): 291-315.

Solano G (2014) Multifocal business practices: the case of Moroccan import/export businesses in Milan. In: Bernhard I. (ed.) Geography of Growth. Trollhättan, University of West, pp 747-766.

Sommer L, Haug M (2011) Intention as a cognitive antecedent to international entrepreneurship understanding the moderating roles of knowledge and experience. Int Entrep Manag J 7: 111-142.

Stevenson HH, Jarillo JC (1990) A paradigm of entrepreneurship: entrepreneurial management. Strat Manag J 11: 17-27.

Sui S, Morgan HM, Baum M (2015) Internationalization of immigrant-owned SMEs: The role of language. J World Bus 50(4): 804-814. 
Sundararajan M, Sundararajan B (2015) Immigrant capital and entrepreneurial opportunities. Entrep Bus Econ Rev 3(3): 29-50.

Tan A, Brewer P, Liesch PW (2007) Before the first export decision: internationalization readiness in the pre-export phase. Int Bus Rev 16: 294-309.

Terjesen S, Elam A (2009) Transnational Entrepreneurs' Venture Internationalization Strategies: A Practice Theory Approach. Entrep Theory Pract 33(5): 1093-1120.

The Economist (2008). Special Report: Migration. Retrieved from http://www.economist.com/printedition/2008-01-05. January 5.

Tumasjan A, Welpe I, Spörrle M (2013) Easy now, desirable later: The moderating role of temporal distance in opportunity evaluation and exploitation. Entrep Theory Pract 37(4): 859-888.

Ucbasaran D, Westhead P, Wright M (2009) The extent and nature of opportunity identification by experienced entrepreneurs. J Bus Vent 24(2): 99-115.

U.S. Department of Commerce (2015) A Basic Guide to Exporting. 11 ${ }^{\text {th }}$ edition. Washinghton, U.S. Department of Commerce. http://export.gov/basicguide/?utm_source=hero\&utm_medium=exportgov\%20\&utm_campaign=bas icguide. Accessed 23 September 2015.

Vandor P, Franke N (2016) See Paris and... found a business? The impact of cross-cultural experience on opportunity recognition capabilities. J Bus Vent 31: 388-407.

Waldinger R, Aldrich H, Ward R (1990) Ethnic Entrepreneurs: Immigrant Business in Industrial Societies. Newbury Park, Sage Publications.

Wang Q, Liu CY (2015) Transnational activities of immigrant-owned firms and their performances in the USA. Small Bus Econ 44(2): 345-359.

Westhead P, Wright M, Ucbasaran D (2001) The internationalization of new and small firms: a resourcebased view. J Bus Vent 16(4): 333-358. 
Wiedersheim-Paul F, Welch L, Olson HC (1978) Pre-export activity: the first step in internationalization. J Man Stud, October: 333-345.

Wright M, Westhead P, Ucbasaran D (2007) Internationalization of small and medium-sized enterprises (SMEs) and international entrepreneurship: a critique and policy implications. Reg Stud 41(7): 10131030.

Zahra SA, Garvis DM (2000) International corporate entrepreneurship: The moderating effect of international environmental hostility. J Bus Vent 15: 469-492.

Zahra S, George G (2002) International entrepreneurship: The current status of the field and future research agenda. In Hitt MA, Ireland RD, Camp SM, Sexton, DL (eds.) Strategic entrepreneurship: Creating a new mindset. Oxford, Blackwell Publishers, pp 255-288.

Zahra SA, Ireland RD, Hitt MA (2000) International expansion by new venture firms: international diversity, mode of market entry, technological learning and performance. Acad Manag J 43(5): 925950.

Zahra SA, Korri JS, Yu J (2005) Cognition and international entrepreneurship: implications for research on international opportunity recognition and exploitation. Int Bus Rev 14(2): 129-146.

Zhao H, Seibert SE, Hills GE (2005) The mediating role of self-efficacy in the development of entrepreneurial intentions. J App Psychol 90(6): 1265-1272.

Zhou M (2004) Revisiting ethnic entrepreneurship: convergences, controversies, and conceptual advancements. Int Migrat Rev 38(3): 1040-1074.

Zou S, Stan S (1998) The determinants of export performance: a review of the empirical literature between 1987 and 1997. Int Mark Rev 15(5): 333-356. 


\section{APPENDIX}

Table A1 - Industries investigated

\begin{tabular}{ll}
\hline Extended description of activity & \\
\hline $\begin{array}{l}\text { Production of pharmaceuticals } \\
\text { Production of computers, electronic and optical products; electro- }\end{array}$ & High-Tech \\
medical equipments, measurement equipments and watches & High-Tech \\
$\begin{array}{l}\text { Production of electrical equipments and non-electrical equipments for } \\
\text { domestic purposes }\end{array}$ & High-Tech \\
$\begin{array}{l}\text { Production of machineries } \\
\text { Production of transport devices and machines }\end{array}$ & Medium-Tech \\
$\begin{array}{l}\text { Production of medical and dental instruments and supplies } \\
\text { Installing of electrical and electronical plants and equipments }\end{array}$ & Medium-Tech \\
$\begin{array}{l}\text { Production of software, informatics consultancy and connected } \\
\text { activities }\end{array}$ & High-Tech \\
ICT services and other informatics services & High-Tech \\
\hline
\end{tabular}

Table A2 - Summary of the sample selection process for immigrant entrepreneurs' firms

\begin{tabular}{|c|c|}
\hline $\begin{array}{l}\text { 1) Full population established by at least a foreign-born partner in high-tech and } \\
\text { machinery sector, period } 2000-2011\end{array}$ & $\mathrm{n}=560$ \\
\hline 2) Non-independent companies to be excluded & $\mathrm{n}=53$ \\
\hline 3) Firms starting a failure process to be excluded & $\mathrm{n}=37$ \\
\hline Subtotal A) Independent active firms & $\mathrm{n}=470$ \\
\hline 4) Companies with no contact to be excluded & $\mathrm{n}=194(*)$ \\
\hline 5) Companies already active on international markets to be excluded & $\mathrm{n}=60$ \\
\hline 6) Companies not reachable through any contact (4 rounds of contacts) & $\mathrm{n}=69$ \\
\hline 7) Companies where the foreign-born partner is not active & $\mathrm{n}=7$ \\
\hline Subtotal B) Independent, active, non-international companies to be included & $\mathrm{n}=140$ \\
\hline 8) Companies not interested in the project & $\mathrm{n}=69$ \\
\hline Subtotal C) Independent, active, non-international companies interviewed & $\mathrm{n}=71$ \\
\hline 9) Companies owned by "chance" foreign-born entrepreneurs & $\mathrm{n}=17$ \\
\hline Subtotal D) Independent, active, non-international, ethnic-immigrant-owned companies & $\mathrm{n}=54$ \\
\hline 10) Companies owned by immigrant entrepreneurs from OECD countries & $\mathrm{n}=17$ \\
\hline $\begin{array}{l}\text { Subtotal E) Independent, active, non-international, developing-country-immigrant-owned } \\
\text { companies }\end{array}$ & $\mathrm{n}=37$ \\
\hline
\end{tabular}

(*) This number reflects a documented problem in the management of the Italian business official directories, where many inactive, failed or closed firms do not officially close their position at the Chamber of Commerce. To this extent, the regulation D.P.R. 247/2004 established a procedure to allow the default deletion from the business directories after three years of missing documentation. This problem might be further exacerbated by the peculiarity of the selected sample (foreign-born entrepreneurs), for different reasons (e.g., individuals who opened a firm just as a means of obtaining a work visa for Italy and do not carry out any 'real' activity or left the country; individuals whose firms failed or closed down and were not aware that they have to close their position at the Chamber of Commerce; etc.). Because it was not possible to find these firms in any manner, we do not consider these firms in the calculation of our response rate. 
Table A3 - Localization of firms

\begin{tabular}{lcccc}
\hline Province & \multicolumn{2}{c}{ Sample } & \multicolumn{2}{c}{ Regional population ${ }^{\text {a }}$} \\
\hline Piacenza & N & \% on total & N & \% on total \\
Parma & 6 & $4.3 \%$ & 23,818 & $6.2 \%$ \\
Reggio Emilia & 17 & $12.1 \%$ & 38,525 & $10.1 \%$ \\
Modena & 15 & $10.7 \%$ & 43,695 & $11.4 \%$ \\
Bologna & 25 & $17.9 \%$ & 59,990 & $15.7 \%$ \\
Ferrara & 34 & $24.3 \%$ & 89,139 & $23.3 \%$ \\
Ravenna & 9 & $6.4 \%$ & 26,202 & $6.9 \%$ \\
Forlì-Cesena & 11 & $7.9 \%$ & 30,923 & $8.1 \%$ \\
Rimini & 0 & $.0 \%$ & 35,280 & $9.2 \%$ \\
\hline Total & 23 & $16.4 \%$ & 34,614 & $9.1 \%$ \\
\hline
\end{tabular}

a Source: ISTAT, Asia archives (2010)

Table A4 - Firms' characteristics: native- vs. foreign-born-owned firms

\begin{tabular}{|c|c|c|c|c|c|c|c|}
\hline & \multicolumn{3}{|c|}{ Native-owned } & \multicolumn{3}{|c|}{ Foreign-born-owned } & \multirow[b]{2}{*}{$\begin{array}{c}\text { Difference } \\
\text { p-value }\end{array}$} \\
\hline & $\mathbf{N}$ & Mean & SD & $\mathbf{N}$ & Mean & SD & \\
\hline Firm age & 69 & 6.04 & 3.52 & 71 & 5.69 & 3.88 & .574 \\
\hline N. of employees (t-1) & 69 & 4.06 & 1.06 & 71 & 3.87 & 6.06 & .885 \\
\hline N. of partners $(t-1)$ & 69 & 2.33 & 1.60 & 71 & 2.58 & 1.99 & .426 \\
\hline Financial capital & 69 & $33,971.01$ & $43,739.78$ & 71 & $69,361.97$ & $176,081.90$ & .107 \\
\hline Previous internationaliz. & 69 & .20 & .41 & 71 & .14 & .35 & .334 \\
\hline$\%$ of business-to-business sales & 69 & 90.74 & 24.75 & 71 & 94.63 & 17.71 & .282 \\
\hline$\%$ of regional clients & 69 & 69.35 & 32.91 & 71 & 75.32 & 29.70 & .261 \\
\hline$\%$ of Italian-nationals clients & 69 & 96.52 & 17.03 & 71 & 97.22 & 13.41 & .786 \\
\hline$\%$ of regional suppliers & 69 & 64.89 & 36.05 & 71 & 55.51 & 41.42 & .155 \\
\hline$\%$ of Italian-nationals suppliers & 69 & 82.07 & 38.07 & 71 & 77.18 & 41.99 & .472 \\
\hline$\%$ of regional competitors & 69 & 60.20 & 38.39 & 71 & 58.13 & 38.78 & .751 \\
\hline
\end{tabular}


Table A5 - Entrepreneurs' country of birth

\begin{tabular}{|c|c|c|}
\hline & Frequency & Percent \\
\hline Albania & 5 & 3.57 \\
\hline Argentina & 6 & 4.29 \\
\hline Belgium & 3 & 2.14 \\
\hline Bolivia & 1 & .71 \\
\hline Brasil & 2 & 1.43 \\
\hline Cameroon & 1 & .71 \\
\hline Canada & 3 & 2.14 \\
\hline Czech Republic & 1 & .71 \\
\hline China & 1 & .71 \\
\hline Colombia & 1 & .71 \\
\hline Ethiopia & 1 & .71 \\
\hline France & 5 & 3.57 \\
\hline Germany & 4 & 2.86 \\
\hline Greece & 1 & .71 \\
\hline Italy & 69 & 49.29 \\
\hline Ivory Coast & 1 & .71 \\
\hline Libia & 1 & .71 \\
\hline Moldova & 2 & 1.43 \\
\hline Morocco & 6 & 4.29 \\
\hline Pakistan & 2 & 1.43 \\
\hline Peru & 1 & .71 \\
\hline Poland & 3 & 2.14 \\
\hline Romania & 1 & .71 \\
\hline Russia & 2 & 1.43 \\
\hline Sweden & 1 & .71 \\
\hline Switzerland & 7 & 5.00 \\
\hline Taiwan & 1 & .71 \\
\hline Tunisia & 1 & .71 \\
\hline UK & 3 & 2.14 \\
\hline USA & 3 & 2.14 \\
\hline Venezuela & 1 & .71 \\
\hline Total & 140 & 100.0 \\
\hline
\end{tabular}


Table A6 - Entrepreneurs' characteristics: Native vs. foreign-born entrepreneurs

\begin{tabular}{lrrr|rrr|c}
\hline & \multicolumn{3}{c}{ Native } & \multicolumn{3}{c|}{ Foreign-born } & \\
\hline & $\mathbf{N}$ & Mean & SD & N & Mean & SD & $\begin{array}{c}\text { Difference } \\
\text { p-value }\end{array}$ \\
\hline Entrepreneur gender (male) & 69 & .81 & .39 & 71 & .72 & .45 & .196 \\
Entrepreneur age & 69 & 41.71 & 8.25 & 71 & 41.24 & 8.21 & .736 \\
Years of education & 69 & 14.59 & 3.34 & 71 & 15.45 & 3.08 & .123 \\
Years of work experience & 69 & 13.18 & 9.03 & 71 & 12.22 & 7.43 & .493 \\
Years of work in Italy & 69 & 13.71 & 9.02 & 71 & 10.50 & 7.75 & .062 \\
Portfolio entrepreneur (a) & 69 & .22 & .41 & 71 & .29 & .45 & .292 \\
Years working as entrepreneur & 69 & 9.83 & 6.63 & 71 & 8.93 & 7.04 & .439 \\
Years international work experience & 69 & .78 & 3.19 & 71 & .66 & 1.78 & .789 \\
Foreign language (b) & 69 & .91 & .28 & 71 & .98 & .12 & .048 \\
English language proficiency (c) & 69 & 1.86 & 1.18 & 71 & 2.34 & 1.30 & .022 \\
Necessity entrepreneur & 69 & .19 & .39 & 71 & .28 & .45 & .196 \\
\hline
\end{tabular}

(a) Dummy variable being 1 if the entrepreneur is owner of other companies, 0 otherwise.

(b) Dummy variable being 1 if the entrepreneur speaks at least one foreign language (besides Italian, for immigrants), 0 otherwise.

(c) Proficiency of English language on a scale ranging from 0 (not spoken) to 4 (fluent). 
Table A7 - Robustness check -- adding control variable (cultural orientation towards the host country)

\begin{tabular}{|c|c|c|c|}
\hline \multirow[b]{2}{*}{ Variables } & \multicolumn{3}{|c|}{$\begin{array}{l}\text { Migrant condition: } \\
\text { foreign-born entrepreneur }\end{array}$} \\
\hline & Model 1 & Model 2 & Model 3 \\
\hline Entrepreneur age & $\begin{array}{c}.02 \\
(.017)\end{array}$ & $\begin{array}{c}.02 \\
(.018)\end{array}$ & $\begin{array}{c}.02 \\
(.018)\end{array}$ \\
\hline Entrepreneur education & $\begin{array}{c}.07 \\
(.045)\end{array}$ & $\begin{array}{c}.03 \\
(.044)\end{array}$ & $\begin{array}{c}.02 \\
(.044)\end{array}$ \\
\hline Entrepreneur gender & $\begin{array}{l}.06 \\
(.335)\end{array}$ & $\begin{array}{l}-.26 \\
(.340)\end{array}$ & $\begin{array}{l}-.36 \\
(.342)\end{array}$ \\
\hline Firm age & $\begin{array}{c}.01 \\
(.038)\end{array}$ & $\begin{array}{c}.04 \\
(.039)\end{array}$ & $\begin{array}{c}.03 \\
(.038)\end{array}$ \\
\hline Firm size & $\begin{array}{c}.03 \# \\
0.019)\end{array}$ & $\begin{array}{l}.04^{*} \\
(.018)\end{array}$ & $\begin{array}{l}.04^{*} \\
(.018)\end{array}$ \\
\hline Industry & $\begin{array}{l}-.12 \\
(.314)\end{array}$ & $\begin{array}{l}-.30 \\
(.306)\end{array}$ & $\begin{array}{l}-.25 \\
(.300)\end{array}$ \\
\hline Firm past internationalization & $\begin{array}{c}.78^{*} \\
(.378)\end{array}$ & $\begin{array}{c}.41 \\
(.368)\end{array}$ & $\begin{array}{c}.21 \\
(.366)\end{array}$ \\
\hline Firm members' internat. business skills & $\begin{array}{c}.04 \\
(.080)\end{array}$ & $\begin{array}{c}.00 \\
(.078)\end{array}$ & $\begin{array}{c}-.01 \\
(.077)\end{array}$ \\
\hline Financial capital & $\begin{array}{c}-.01 \\
(.069)\end{array}$ & $\begin{array}{c}-.04 \\
(.067)\end{array}$ & $\begin{array}{l}-.06 \\
(.065)\end{array}$ \\
\hline Orientation towards host country & $\begin{array}{c}.05 \\
(.175)\end{array}$ & $\begin{array}{c}-.32 \\
(.212)\end{array}$ & $\begin{array}{c}-.28 \\
(.208)\end{array}$ \\
\hline Migrant condition (MIG) & & $\begin{array}{l}-.90 * \\
(.348)\end{array}$ & $\begin{array}{l}-.89 * * \\
(.340)\end{array}$ \\
\hline International business skills & & $\begin{array}{l}.35 * * * \\
(.104)\end{array}$ & $\begin{array}{l}.64 * * * \\
(.150)\end{array}$ \\
\hline Entrepreneurial experience & & $\begin{array}{c}-.01 \\
(.023)\end{array}$ & $\begin{array}{c}-.03 \\
(.029)\end{array}$ \\
\hline Perceived financial govern. support & & $\begin{array}{l}.15^{*} \\
(.075)\end{array}$ & $\begin{array}{c}.03 \\
(.094)\end{array}$ \\
\hline Perceived regulatory support & & $\begin{array}{c}.03 \\
(.089)\end{array}$ & $\begin{array}{c}-.07 \\
(.111)\end{array}$ \\
\hline International business skills*MIG & & & $\begin{array}{l}-.47 * \\
(.188)\end{array}$ \\
\hline Entrepreneurial experience*MIG & & & $\begin{array}{l}.04 \\
(.038)\end{array}$ \\
\hline Perceived financial govern. support*MIG & & & $\begin{array}{c}.22 \\
(.146)\end{array}$ \\
\hline Perceived regulatory support*MIG & & & $\begin{array}{c}.26 \\
(.178)\end{array}$ \\
\hline Constant & $\begin{array}{c}.36 \\
(1.487)\end{array}$ & $\begin{array}{c}3.97 * \\
(1.784)\end{array}$ & $\begin{array}{c}4.34^{*} \\
(1.739)\end{array}$ \\
\hline Observations & 140 & 140 & 140 \\
\hline R-squared & .11 & .24 & .31 \\
\hline$\Delta \mathrm{R}$-squared & - & $.13 * *$ & $.07 *$ \\
\hline Adj. R-squared & .04 & .15 & .20 \\
\hline
\end{tabular}

Standard errors in parentheses

$* * * \mathrm{p}<.001, * * \mathrm{p}<.01, * \mathrm{p}<.05, \# \mathrm{p}<.1$

All VIFs between 1.19 and 3.66 